\title{
Structure and Function of $\mathrm{IP}_{3}$ Receptors
}

\author{
David L. Prole and Colin W. Taylor \\ Department of Pharmacology, University of Cambridge, Cambridge CB2 1PD, United Kingdom \\ Correspondence: cwt1000@cam.ac.uk
}

Inositol 1,4,5-trisphosphate receptors $\left(\mathrm{IP}_{3} \mathrm{Rs}\right)$, by releasing $\mathrm{Ca}^{2+}$ from the endoplasmic reticulum (ER) of animal cells, allow $\mathrm{Ca}^{2+}$ to be redistributed from the ER to the cytosol or other organelles, and they initiate store-operated $\mathrm{Ca}^{2+}$ entry (SOCE). For all three $\mathrm{IP}_{3} \mathrm{R}$ subtypes, binding of $\mathrm{IP}_{3}$ primes them to bind $\mathrm{Ca}^{2+}$, which then triggers channel opening. We are now close to understanding the structural basis of $\mathrm{IP}_{3} \mathrm{R}$ activation. $\mathrm{Ca}^{2+}$-induced $\mathrm{Ca}^{2+}$ release regulated by $I_{3}$ allows $I P_{3}$ Rs to regeneratively propagate $\mathrm{Ca}^{2+}$ signals. The smallest of these regenerative events is a $\mathrm{Ca}^{2+}$ puff, which arises from the nearly simultaneous opening of a small cluster of $\mathrm{IP}_{3} \mathrm{Rs}$. $\mathrm{Ca}^{2+}$ puffs are the basic building blocks for all $\mathrm{IP}_{3}$-evoked $\mathrm{Ca}^{2+}$ signals, but only some $\mathrm{IP}_{3}$ clusters, namely those parked alongside the ER-plasma membrane junctions where SOCE occurs, are licensed to respond. The location of these licensed $I P_{3} R s$ may allow them to selectively regulate SOCE.

nositol 1,4,5-trisphosphate receptors $\left(\mathrm{IP}_{3} \mathrm{Rs}\right)$ are expressed in most animal cells, including single-celled protozoa (Prole and Taylor 2011). They mediate release of $\mathrm{Ca}^{2+}$ from intracellular stores, primarily the endoplasmic reticulum (ER) (Berridge 1993) and Golgi apparatus (Pizzo et al. 2011; Wong et al. 2013; Rodriguez-Prados et al. 2015). $\mathrm{IP}_{3} \mathrm{Rs}$ are also expressed in the nuclear envelope and nucleoplasmic reticulum (Echevarría et al. 2003), where they may selectively generate nuclear $\mathrm{Ca}^{2+}$ signals, although cytosolic $\mathrm{Ca}^{2+}$ signals also invade the nucleoplasm (Bading 2013). $\mathrm{IP}_{3} \mathrm{R}$-mediated $\mathrm{Ca}^{2+}$ fluxes across ER membranes increase the cytosolic $\mathrm{Ca}^{2+}$ concentration $\left(\left[\mathrm{Ca}^{2+}\right]_{\mathrm{c}}\right)$, and when these signals occur close to other organelles, mitochondria (Csordas et al. 2018) or lysosomes (Lopez Sanjurjo et al. 2013; Garrity et al. 2016; Atakpa et al. 2018), for example, they allow their low-affinity uptake systems to resequester the $\mathrm{Ca}^{2+}$. The accompanying decrease in ER luminal $\mathrm{Ca}^{2+}$ concentration is also important because it activates stromal interaction molecule 1 (STIM1), which then accumulates at ER-plasma membrane (PM) junctions. Within these narrow junctions, STIM1 in the ER membrane interacts directly with Orail, which is a hexameric $\mathrm{Ca}^{2+}$ channel in the PM (Hou et al. 2012; Yen and Lewis 2018), causing it to open (Prakriya and Lewis 2015). The resulting store-operated $\mathrm{Ca}^{2+}$ entry (SOCE) is almost universally associated with $\mathrm{IP}_{3}$-evoked $\mathrm{Ca}^{2+}$ release. Hence, in response to the many extracellular stimuli that evoke $\mathrm{IP}_{3}$ formation, $\mathrm{IP}_{3}$ Rs allow $\mathrm{Ca}^{2+}$ to be rapidly redistributed from the ER to the cytosol or other organelles and, by controlling the $\mathrm{Ca}^{2+}$ content of the ER, $\mathrm{IP}_{3} \mathrm{Rs}$ control $\mathrm{Ca}^{2+}$ flowing into the cell through SOCE (Fig. 1).

Editors: Geert Bultynck, Martin D. Bootman, Michael J. Berridge, and Grace E. Stutzmann

Additional Perspectives on Calcium Signaling available at www.cshperspectives.org

Copyright (C) 2019 Cold Spring Harbor Laboratory Press; all rights reserved; doi: 10.1101/cshperspect.a035063

Cite this article as Cold Spring Harb Perspect Biol 2019;11:a035063 

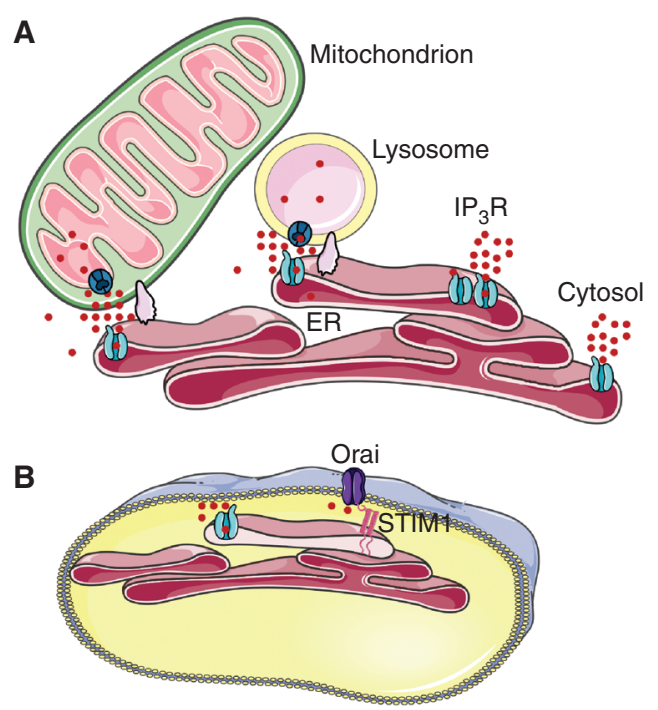

Figure 1. $\mathrm{IP}_{3}$ receptors deliver $\mathrm{Ca}^{2+}$ to the cytosol and organelles. (A) By releasing $\mathrm{Ca}^{2+}$ from the endoplasmic reticulum (ER), $\mathrm{IP}_{3} \mathrm{Rs}$ can deliver $\mathrm{Ca}^{2+}$ to the cytosol, to other $\mathrm{IP}_{3} \mathrm{Rs}$ to ignite regenerative signals, or to the close appositions (membrane contact sites, supported by scaffold proteins) between the ER and other organelles. The latter include mitochondria and lysosomes, which can then accumulate $\mathrm{Ca}^{2+}$ via their low-affinity uptake systems from the high local $\mathrm{Ca}^{2+}$ concentration provided by $\mathrm{IP}_{3}$ Rs. $(B)$ Loss of $\mathrm{Ca}^{2+}$ from the ER also activates STIM1, which then binds to Orai at ER-plasma membrane (PM) junctions to initiate store-operated $\mathrm{Ca}^{2+}$ entry (SOCE).

The cytosolic $\mathrm{Ca}^{2+}$ signals evoked by $\mathrm{IP}_{3} \mathrm{Rs}$ or SOCE regulate diverse physiological responses, including exocrine secretion (Futatsugi et al. 2005), gluconeogenesis (Wang et al. 2012), embryological development (Kume et al. 1997; Uchida et al. 2010), transcription (Kar et al. 2012), nerve growth (Takei et al. 1998), and migration (Wei et al. 2009). The ability of $\mathrm{IP}_{3} \mathrm{Rs}$ to deliver $\mathrm{Ca}^{2+}$ to the mitochondrial uniporter (MCU) allows regulation of oxidative phosphorylation (Cardenas et al. 2010, 2016) and apoptosis (La Rovere et al. 2016), and $\mathrm{Ca}^{2+}$ delivery to lysosomes may allow them to accumulate $\mathrm{Ca}^{2+}$, which regulates their activities $\mathrm{Xu}$ and Ren 2015). Dysregulation of $\mathrm{IP}_{3} \mathrm{Rs}$ is implicated in human diseases including Huntington's disease, Alzheimer's disease, amyotrophic lateral sclerosis, ataxias, autism, and cancer (Berridge 2016).
Despite the importance of $\mathrm{IP}_{3} \mathrm{Rs}$ in both normal physiology and disease, the only known antagonists of $\mathrm{IP}_{3} \mathrm{Rs}$ (heparin, caffeine, and Xestospongin) lack specificity (Saleem et al. 2014). There is a pressing need for selective, membranepermeant $\mathrm{IP}_{3} \mathrm{R}$ antagonists.

$\mathrm{Ca}^{2+}$-binding sites, which include those on the proteins that decode $\mathrm{Ca}^{2+}$ signals, are so abundant in cytosol that only some $1 \%$ of $\mathrm{Ca}^{2+}$ entering the cytosol remains free, although that buffering capacity does vary widely between cell types (Schwaller 2012). A cytosolic $\mathrm{Ca}^{2+}$ ion therefore spends the most time held by a buffer with which it moves more slowly than when free, and when it dissociates it is likely to diffuse freely for only a brief interval before it is recaptured by another buffer. Schwaller (2012) has suggested an apt analogy with Velcro to describe this behavior, which ensures that cytosolic $\mathrm{Ca}^{2+}$ diffuses slowly (Allbritton et al. 1992). This is an important feature that allows $\mathrm{Ca}^{2+}$ to linger at open channels and underpins its ability to serve as a local messenger. Hitherto, it has been assumed that $\mathrm{IP}_{3}$ diffuses freely in cytosol, based largely on measurements from cytoplasmic extracts of Xenopus oocytes in a rightly influential paper (Allbritton et al. 1992). Hence, the widely promulgated assumption has been that $\mathrm{Ca}^{2+}$ is a local messenger, while $\mathrm{IP}_{3}$ is a global messenger. However, $\mathrm{IP}_{3} \mathrm{Rs}$ in Xenopus ooctyes are concentrated in a narrow rim beneath the PM, whereas they are distributed throughout the cytoplasm of more typical cells (Thillaiappan et al. 2017). The cytoplasmic density of $\mathrm{IP}_{3}$ Rs considered alongside their affinity for $\mathrm{IP}_{3}$ and the necessity for an $\mathrm{IP}_{3} \mathrm{R}$ to bind four molecules of $\mathrm{IP}_{3}$ before it can open (Alzayady et al. 2016) suggest that $\mathrm{IP}_{3} \mathrm{Rs}$ may, and prior to their activation, appreciably buffer $\mathrm{IP}_{3}$ (Taylor and Konieczny 2016). Estimates of $\mathrm{IP}_{3}$ diffusion in SH-SY5Y neuroblastoma cells, derived from measuring the extent to which $\mathrm{IP}_{3}$ focally released from a caged precursor spreads to initiate local $\mathrm{Ca}^{2+}$ signals, have elegantly confirmed that diffusion of $\mathrm{IP}_{3}$ in cells (diffusion coefficient, $D \sim 10 \mu \mathrm{m}^{2} / \mathrm{sec}$ ) is $\sim 30$-fold slower than expected (Dickinson et al. 2016) and comparable to $\mathrm{Ca}^{2+}$ diffusion $\left(D=13-65 \mu^{2} / \mathrm{sec}\right.$ ) (Allbritton et al. 1992). This suggests that both intracellular messengers, 
$\mathrm{IP}_{3}$ and $\mathrm{Ca}^{2+}$, can act locally within the confines of a typical cell (Dickinson et al. 2016). The activities of many cells are coordinated by $\mathrm{Ca}^{2+}$ waves that spread between cells (Leybaert and Sanderson 2012). Diffusion of $\mathrm{IP}_{3}$ through intercellular gap junctions is one means by which such $\mathrm{Ca}^{2+}$ waves are thought to propagate, but that idea was influenced by the assumption that $\mathrm{IP}_{3}$ diffusion is unhindered (Leybaert 2016). The discovery that $\mathrm{IP}_{3}$ diffuses slowly may require reappraisal of current thinking on how intercellular $\mathrm{Ca}^{2+}$ waves propagate and it invites speculation that there may be "highways" between cells wherein $\mathrm{IP}_{3}$ buffering is reduced to facilitate faster intercellular diffusion.

In a contribution to the first edition of this collection, we reviewed the history of $\mathrm{IP}_{3} \mathrm{Rs}$ (Taylor and Tovey 2012), noting that it was entwined with that of ryanodine receptors (RyRs), the close cousins of $\mathrm{IP}_{3} \mathrm{Rs}$. The cross fertilization between studies of these two major families of intracellular $\mathrm{Ca}^{2+}$ release channels, with their many structural and functional similarities (Seo et al. 2012; des Georges et al. 2016), continues to provide important insight. That interplay will again be apparent in this review. We focus on recent progress toward understanding the structural basis of $\mathrm{IP}_{3} \mathrm{R}$ activation, evidence that $\mathrm{IP}_{3}$ Rs are regulated by many additional proteins, and the organization of $\mathrm{IP}_{3}$ Rs within ER membranes and the implications of that for SOCE. Other reviews provide readers with broader overviews (Foskett et al. 2007), historical perspectives (Berridge 2005; Rossi and Taylor 2019), and more focused considerations of $\mathrm{IP}_{3} \mathrm{Rs}$ and disease (Berridge 2016; Hisatsune and Mikoshiba 2017; Egorova and Bezprozvanny 2018), their regulation by proteolysis (Wang and Yule 2018) and other signals (Prole and Taylor 2016; Taylor 2017), the evolution of $\mathrm{IP}_{3}$ Rs (Alzayady et al. 2015), and relationships between SOCE and $\mathrm{IP}_{3} \mathrm{Rs}$ (Taylor and Machaca 2019; Thillaiappan et al. 2019). We begin with a short overview of $\mathrm{IP}_{3}$ Rs.

\section{IP $_{3}$ RECEPTORS ARE REGULATED BY IP ${ }_{3}$ AND $\mathrm{Ca}^{2+}$}

Vertebrate genomes encode subunits for three closely related $\mathrm{IP}_{3} \mathrm{R}$ subunits $\left(\mathrm{IP}_{3} \mathrm{R} 1-3\right)$, which assemble into homo- and heterotetrameric channels. The subunits are enormous $(\sim 2700$ residues), such that $\mathrm{IP}_{3} \mathrm{Rs}$ and RyRs (which are even larger, $4 \times \sim 5000$ residues/RyR) are the largest known ion channels. The $\mathrm{IP}_{3} \mathrm{R}$ subtypes differ in their patterns of expression between tissues (Taylor et al. 1999) and perhaps in their subcellular distributions (Vervloessem et al. 2015), they have different affinities for $\mathrm{IP}_{3}$ $\left(\mathrm{IP}_{3} \mathrm{R} 2>\mathrm{IP}_{3} \mathrm{R} 1>\mathrm{IP}_{3} \mathrm{R} 3\right.$ ) (Iwai et al. 2007), they differ in their associations with other proteins and in their modulation by additional signals (Prole and Taylor 2016), they appear to differ in their capacity to sustain oscillatory $\mathrm{Ca}^{2+}$ signals (Miyakawa et al. 1999; Wang and Yule 2018), and the functional consequences of perturbing $\mathrm{IP}_{3} \mathrm{Rs}$ differ for the different subtypes (Hisatsune and Mikoshiba 2017). Despite the differences, the core functional properties of all $\mathrm{IP}_{3} \mathrm{Rs}$ are similar and so too are their structures, consistent with the sequence conservation ( 70\%) between subtypes (Fan et al. 2015, 2018; Paknejad and Hite 2018). All $\mathrm{IP}_{3}$ Rs form largeconductance cation channels with relatively weak selectivity for $\mathrm{Ca}^{2+}$ over $\mathrm{K}^{+}\left(\mathrm{P}_{\mathrm{Ca}} / \mathrm{P}_{\mathrm{K}} \sim 7\right)$ (Foskett et al. 2007). The large conductance, which allows a single $\mathrm{IP}_{3} \mathrm{R}$ to conduct $\sim 10^{5}$ $\mathrm{Ca}^{2+} / \mathrm{sec}$ or $1000 \mathrm{Ca}^{2+}$ ions for each $10-\mathrm{msec}$ opening (Vais et al. 2010), is important because it permits small numbers of $\mathrm{IP}_{3}$ Rs to rapidly deliver large local $\mathrm{Ca}^{2+}$ signals to the cytosol. The second feature common to all $\mathrm{IP}_{3} \mathrm{Rs}$, although historically it has spawned some controversy, is their biphasic regulation by $\left[\mathrm{Ca}^{2+}\right]_{\mathrm{c}}$. The activity of all $\mathrm{IP}_{3} \mathrm{Rs}$ is enhanced by modest increases in $\left[\mathrm{Ca}^{2+}\right]_{\mathrm{c}}$ and inhibited by more substantial increases (Iino 1990; Bezprozvanny et al. 1991; Foskett et al. 2007). Whether $\mathrm{IP}_{3} \mathrm{Rs}$ are also regulated directly by $\mathrm{Ca}^{2+}$ within the ER lumen remains a contentious and unresolved issue (Irvine 1990; Nunn and Taylor 1992; Vais et al. 2012).

Activation of $\mathrm{IP}_{3} \mathrm{Rs}$ requires binding of both $\mathrm{IP}_{3}$ to all four of its subunits (Alzayady et al. 2016) and $\mathrm{Ca}^{2+}$ binding (Finch et al. 1991; Marchant and Taylor 1997). The simplest scheme envisages two $\mathrm{Ca}^{2+}$-binding sites associated with the $\mathrm{IP}_{3} \mathrm{R}$ (Marshall and Taylor 1994). Biophysical analyses tentatively suggest that the stimulatory $\mathrm{Ca}^{2+}$-binding site may be closer to 
D.L. Prole and C.W. Taylor

the pore than the inhibitory site (Vais et al. 2012). Different schemes have been proposed to explain the interaction between $\mathrm{IP}_{3}$ and $\mathrm{Ca}^{2+}$, with $\mathrm{IP}_{3}$ proposed to regulate only the inhibitory $\mathrm{Ca}^{2+}$-binding site (reducing its affinity for $\mathrm{Ca}^{2+}$ ) (Mak et al. 1998; Vais et al. 2012) or both the inhibitory (reducing its $\mathrm{Ca}^{2+}$ affinity) and stimulatory (increasing its $\mathrm{Ca}^{2+}$ affinity) sites (Marchant and Taylor 1997; Adkins and Taylor 1999). Whatever the detailed mechanism, the outcome is that $\mathrm{IP}_{3}$ primes $\mathrm{IP}_{3} \mathrm{Rs}$ to respond to stimulation by $\mathrm{Ca}^{2+}$, by either divorcing the stimulatory and inhibitory effects, or by directly promoting $\mathrm{Ca}^{2+}$ binding to the stimulatory site (Fig. 2A,B). This interplay has important implications because it allows $\mathrm{IP}_{3} \mathrm{Rs}$, in the presence of $\mathrm{IP}_{3}$, to propagate $\mathrm{Ca}^{2+}$ signals regeneratively by $\mathrm{Ca}^{2+}$-induced $\mathrm{Ca}^{2+}$ release (CICR) (Fig. 2C). We return to this feature later, but first we consider progress toward understanding the structural basis of how $\mathrm{IP}_{3}$ and $\mathrm{Ca}^{2+}$ binding together lead to opening of a large-conductance channel through which $\mathrm{Ca}^{2+}$ can leave the ER.

\section{HOW TO OPEN AN IP 3 RECEPTOR}

How does $\mathrm{IP}_{3}$ binding to a site, the $\mathrm{IP}_{3}$-binding core (IBC), located $\sim 7 \mathrm{~nm}$ from the constriction within the closed channel, lead to channel open- ing? Progress toward answering this question has come from high-resolution crystal structures of the amino-terminal region of the $\mathrm{IP}_{3} \mathrm{R}$, which includes the IBC (Bosanac et al. 2002, 2005; Lin et al. 2011; Seo et al. 2012) and of the entire cytosolic region (Hamada et al. 2017). These analyses capture structures of only one subunit of the tetrameric $\mathrm{IP}_{3} \mathrm{R}$. Cryoelectron microscopy (cryo-EM) structures of $\mathrm{IP}_{3} \mathrm{R} 1$ (Fan et al. 2015, 2018) and of $\mathrm{IP}_{3} \mathrm{R} 3$ with and without $\mathrm{IP}_{3}$ and $\mathrm{Ca}^{2+}$ (Paknejad and Hite 2018) capture different states of the complete protein. Structural analyses of RyR fragments (Amador et al. 2009; Tung et al. 2010; Kimlicka et al. 2013; Liu et al. 2015) and of complete structures of RyR1 and RyR2 in various states (Efremov et al. 2015; Yan et al. 2015; Zalk et al. 2015; des Georges et al. 2016; Peng et al. 2016) also provide insight into the workings of $\mathrm{IP}_{3} \mathrm{Rs}$.

The structure of the $\mathrm{IP}_{3} \mathrm{R}$ resembles a square mushroom, most of which ( 90\%) is in the cytosol (Fig. 3A; Fan et al. 2015; Paknejad and Hite 2018). Most of the stalk is embedded in the ER membrane and the cap, with a diameter of $\sim 25 \mathrm{~nm}$, extends $\sim 13 \mathrm{~nm}$ into the cytosol. The large size of $\mathrm{IP}_{3} \mathrm{Rs}$ is relevant, not only for the opportunities it provides for cryo-EM analysis and the technical challenges it presents to crystallographers and molecular biologists, but also
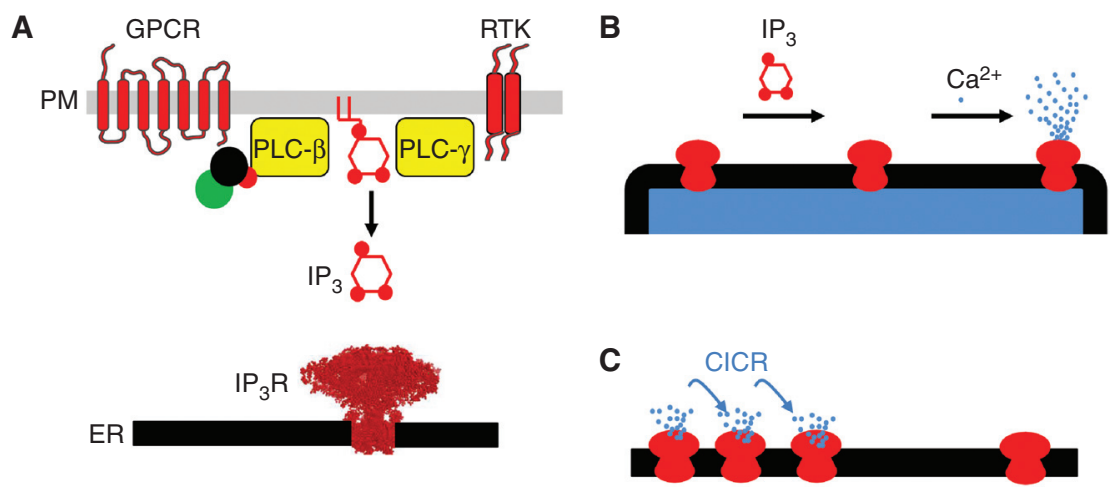

Figure 2. $\mathrm{IP}_{3}$ receptors are stimulated by $\mathrm{IP}_{3}$ and $\mathrm{Ca}^{2+}$. (A) Many receptors, including G-protein-coupled receptors (GPCRs) and receptor tyrosine kinases (RTKs), can stimulate phospholipase C (PLC), leading to production of $\mathrm{IP}_{3}$, which then binds to $\mathrm{IP}_{3} \mathrm{Rs}$ in the endoplasmic reticulum (ER). (B) IP $\mathrm{I}_{3}$ binding to $\mathrm{IP}_{3} \mathrm{R}$ primes them to bind $\mathrm{Ca}^{2+}$, which then stimulates the channel to open, allowing $\mathrm{Ca}^{2+}$ to flow out of the ER. $(C)$ This dual regulation of $\mathrm{IP}_{3} \mathrm{Rs}$ by $\mathrm{IP}_{3}$ and $\mathrm{Ca}^{2+}$ allows them to mediate regenerative signals propagated by $\mathrm{Ca}^{2+}$-induced $\mathrm{Ca}^{2+}$ release (CICR). PM, Plasma membrane. 
$\mathrm{IP}_{3}$ Receptors

A

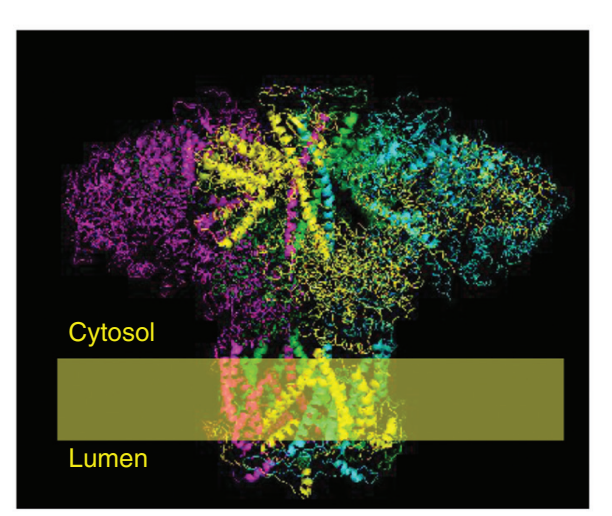

B

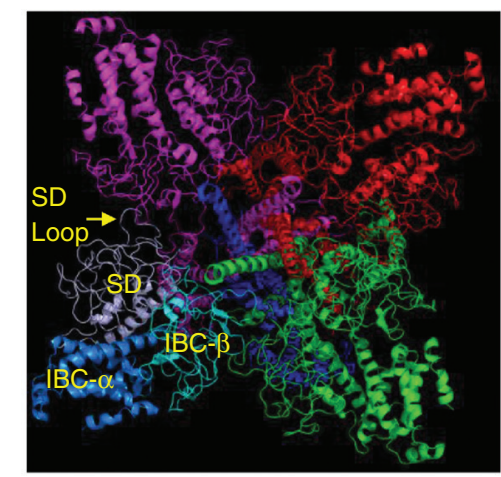

C

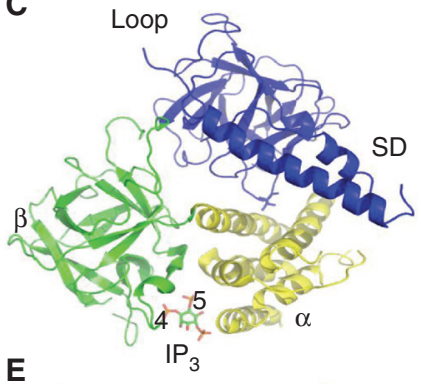

E

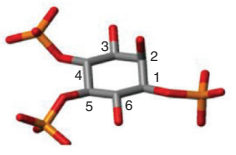

$\mathbb{P}_{3}$

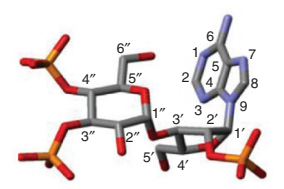

Adenophostin A

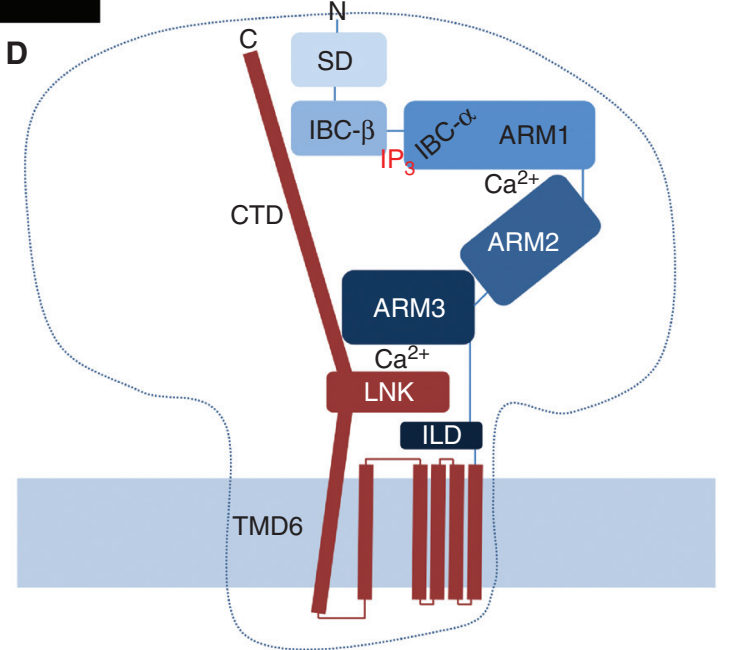

Figure 3. $\mathrm{IP}_{3}$ receptor structure. (A) Cryoelectron microscopy (cryo-EM) of $\mathrm{IP}_{3} \mathrm{R} 1$ shows its tetrameric mushroom-like structure. (From Fan et al. 2015; adapted, with permission, from Springer Nature $\odot$ 2015.) Subunits are color-coded. A similar structure has been reported for $\mathrm{IP}_{3} \mathrm{R} 3$ (Paknejad and Hite 2018). (B) View from the cytosol. $(C)$ The amino-terminal region of each $\mathrm{IP}_{3} \mathrm{R}$ subunit comprises the suppressor domain $(\mathrm{SD})$ with the "hot spot" loop through which it contacts an adjacent subunit; and the IP ${ }_{3}$-binding core (IBC), with its $\alpha$ and $\beta$ domains. The essential 4 - and 5 -phosphates of $\mathrm{IP}_{3}$ interact predominantly with residues on the inner surface of the $\beta$ and $\alpha$ domains, respectively, to trigger partial closure of clam-like IBC. (D) Schematic representation showing a single $\mathrm{IP}_{3} \mathrm{R} 1$ subunit, highlighting the IBC, where $\mathrm{IP}_{3}$ binds, two $\mathrm{Ca}^{2+}$-binding sites at interfaces between ARM1 and ARM2 domains, and between the LNK and ARM3 domains (Paknejad and Hite 2018). The $\alpha$-helical rod (carboxy-terminal domain [CTD]) extending from LNK to the cap of the mushroom was resolved in structures from one laboratory (Fan et al. 2015, 2018), but not in the structures determined by another laboratory (Paknejad and Hite 2018). It is clear that conformational changes initiated by $\mathrm{IP}_{3}$ binding must pass through a critical nexus formed by the LNK (from the pore region) and intervening lateral domains (ILDs) (from the cytosolic domain). (E) Structures of $\mathrm{IP}_{3}$ and adenophostin $\mathrm{A}$, showing how the latter has structures equivalent to the essential 4 - and 5-phosphates of $\mathrm{IP}_{3}$.

for its cellular functions. $\mathrm{IP}_{3}$ Rs may, for example, be too large to fit within the narrow ER-PM junctions where SOCE occurs (Thillaiappan et al. 2017), but their large size allows $\mathrm{IP}_{3}$ Rs to accrete accessory proteins (see below) and it may allow them to more effectively deliver $\mathrm{Ca}^{2+}$ to the surface of juxtaposed organelles, like mitochondria or lysosomes (Fig. 1A).

Within the ER membrane, there are probably 24 transmembrane domains (TMDs), six contributed by residues toward the carboxyterminal end of each $\mathrm{IP}_{3} \mathrm{R}$ subunit, although a 
recent report suggests the possible presence of two additional TMDs between TMD1 and TMD2 in $\mathrm{IP}_{3}$ Rs (Fan et al. 2018; Paknejad and Hite 2018) and perhaps also in RyR (des Georges et al. 2016). The structure of the $\mathrm{IP}_{3} \mathrm{R}$ transmembrane region is similar in RyRs and, to a lesser extent, in voltage-gated cation channels, most of which have six TMDs per subunit. The ionconducting path is lined by the four tilted TMD6 helices, which twist around each other. At the luminal end, there is a short $(\sim 1 \mathrm{~nm})$ "selectivity filter" within which conserved backbone carbonyls may form a cation-binding site, allowing hydrated cations to pass in single file. The selectivity filter, its supporting pore-loop helix and a flexible luminal loop are all formed by residues linking TMD5 to TMD6. Near the cytosolic end of TMD6, a narrow hydrophobic constriction blocks movement of ions in the closed channel. Minimally, the hydrophobic side chains of these residues (Phe $\mathrm{P}^{2586}$ and $\mathrm{Ile}^{2590}$ in $\mathrm{IP}_{3} \mathrm{R} 1$ ) must move for the pore to open, but there may also be changes around the pore helix to displace a positively charged residue ( $\mathrm{His}^{2541}$ ) that might otherwise impede cation movements (Fan et al. 2015). Opening of RyR1 is associated with splaying and bowing of TMD6, such that the occluding hydrophobic side chain is displaced (des Georges et al. 2016). A similar mechanism may open the $\mathrm{IP}_{3} \mathrm{R}$ pore (Fan et al. 2018). TMD6 extends well beyond the ER membrane $(\sim 1.5$ $\mathrm{nm})$ and then terminates in a short $\alpha$-helical bundle (the linker, LNK) that includes a $\mathrm{Zn}^{2+}$ finger motif and aligns parallel with the ER membrane (Fan et al. 2015; Paknejad and Hite 2018). The functional significance of the $\mathrm{Zn}^{2+}$ finger is unknown. Hence, structures formed by the TMD5-6 loop guard the luminal entrance to the pore, while the cytosolic exit is formed by the extended TMD6. Each of these regions is enriched in negatively charged residues that probably contribute to the cation selectivity of the $\mathrm{IP}_{3} \mathrm{R}$.

$\mathrm{IP}_{3}$ binding to the clam-like IBC initiates $\mathrm{IP}_{3} \mathrm{R}$ activation (Fig. 3B,C). The IBC is located toward the amino terminal of the primary sequence of each subunit, and comprises two domains ( $\alpha$ and $\beta$ ), with the pocket between them providing the positively charged residues that interact with $\mathrm{IP}_{3}$ (Bosanac et al. 2002; Seo et al. 2012; Paknejad and Hite 2018). All four subunits must bind $\mathrm{IP}_{3}$ before the channel can open (Alzayady et al. 2016). It is less clear whether all stimulatory $\mathrm{Ca}^{2+}$-binding sites must be occupied for channel opening (Vais et al. 2012). The amino-terminal region forms a triangular structure at the top of the mushroom, with the suppressor domain (SD) (residues 1-223; also known as $\beta$-trefoil domain 1 [BTF1]) and IBC- $\beta$ (BTF2) lining the cytosolic exit at the top of the $\mathrm{IP}_{3} \mathrm{R}$. The subunits interact through a loop within the SD that contacts IBC- $\beta$ of a neighboring subunit (Fig. 3B,C; Seo et al. 2012; Fan et al. 2015; Hamada et al. 2017; Paknejad and Hite 2018). Mutations within this "hot spot" loop disrupt gating of $\mathrm{IP}_{3} \mathrm{R}$ (Yamazaki et al. 2010) and RyR (Amador et al. 2009). IBC- $\alpha$ sits behind the $\beta$-trefoil structures at the tip of a series of largely $\alpha$-helical domains (ARM 1-3) that extend in a boomerang-like shape to meet the LNK domain (Fig. 3A,D).

The two critical phosphate groups of $\mathrm{IP}_{3}(\mathrm{P}-4$ and $\mathrm{P}-5)$ interact predominantly with basic residues (Arg and Lys) lining opposing sides of the IBC clam: P- 4 with IBC- $\beta$ and P-5 with IBC- $\alpha$ (Fig. 3C; Bosanac et al. 2002). These interactions allow $\mathrm{IP}_{3}$ to partially close the clam-like IBC (Lin et al. 2011; Seo et al. 2012; Paknejad and Hite 2018), and they elegantly rationalize the longestablished conclusion that all known agonists of $\mathrm{IP}_{3} \mathrm{Rs}$ have structures equivalent to the 4- and 5-phosphates of $\mathrm{IP}_{3}$. The structures also demonstrate how endogenous dephosphorylation of $\mathrm{IP}_{3}$ to $1,4-\mathrm{IP}_{2}$ effectively terminates $\mathrm{Ca}^{2+}$ signaling. The importance of the clam closure is reinforced by results with adenophostin A analogs. Adenophostin $\mathrm{A}$ is a fungal product with 10-fold greater affinity for $\mathrm{IP}_{3} \mathrm{Rs}$ than $\mathrm{IP}_{3}$, and with structures, its $3^{\prime \prime}$ - and $4^{\prime \prime}$-phosphates, equivalent to the 5- and 4-phosphates of $\mathrm{IP}_{3}$, respectively (Fig. 3E; Rossi et al. 2010; but see Fan et al. 2018). Whereas loss of the 5-phosphate group from $\mathrm{IP}_{3}$ abolishes activity, loss of the equivalent phosphate from adenophostin $\mathrm{A}$ ( $3^{\prime \prime}$-phosphate) leaves some residual activity because the adenine moiety of adenophostin $\mathrm{A}$ can interact with IBC- $\alpha$ and so presumably mediate clam closure in the absence of the usual 
phosphate group (Sureshan et al. 2009). Closure of the clam-like IBC by $\mathrm{IP}_{3}$ binding is linked to $\mathrm{IP}_{3} \mathrm{R}$ gating through the $\mathrm{SD}$, but the exact sequence of conformational changes is unresolved. It may be that movement of IBC- $\alpha$ relative to a firmly anchored IBC- $\beta / S D$ reorients the ARM domains (Paknejad and Hite 2018), or it may be that tethering of IBC- $\alpha$ to the SD causes reorientation of the SD and disruption of intersubunit interactions ( $\mathrm{Li}$ et al. 2009; Seo et al. 2012; des Georges et al. 2016). It is, however, clear that $\mathrm{IP}_{3}$-evoked conformational changes must pass through the contacts between ARM3 and LNK domains to reach the occluded pore (Fig. 3D).

ARM3 terminates in the intervening lateral domain (ILD), which sits between the cytosolic structures and the TMDs. ILD runs largely parallel to the ER membrane, and comprises two $\beta$ strands (which lie immediately beneath ARM3) followed by a helix-turn-helix motif that links to TMD1 (Fig. 3D). The LNK domain (an extension of TMD6) is positioned between the $\beta$ - and $\alpha$-helical components of the ILD. Hence, interleaved structures formed by extensions of ARM3 (ILD) and TMD6 (LNK) form a critical nexus between the cytosolic region and the pore of the $\mathrm{IP}_{3} \mathrm{R}$. Mutations within ILD disrupt $\mathrm{IP}_{3} \mathrm{R}$ function (Hamada et al. 2017), and the LNK domain contributes a conserved residue to a $\mathrm{Ca}^{2+}$-binding site at the base of the ARM3 domain (Fig. 3D; Paknejad and Hite 2018). This $\mathrm{Ca}^{2+}$-binding site, formed by residues at the interface of the cytosolic (base of ARM3) and pore (LNK domain) regions, is absolutely conserved in RyRs and $\mathrm{IP}_{3} \mathrm{Rs}$ (des Georges et al. 2016). We note that in both RyR (Glu ${ }^{4032}$ in RyR1) (Du and MacLennan 1998) and $I_{3} R 1\left(\mathrm{Glu}^{2100}\right)$ (Miyakawa et al. 2001), a conserved glutamate was proposed to contribute to the stimulatory $\mathrm{Ca}^{2+}$-binding site. Indeed, and somewhat perplexingly, mutation of this residue affected both stimulation and inhibition of $\mathrm{IP}_{3} \mathrm{Rs}$ by $\mathrm{Ca}^{2+}$ (Miyakawa et al. 2001). It is now clear from structural analyses that these conserved glutamates do not coordinate $\mathrm{Ca}^{2+}$ in either RyR (des Georges et al. 2016) or $\mathrm{IP}_{3} \mathrm{R}$ (Paknejad and Hite 2018). It is equally clear that the EF-hand domain of RyR, which projects from a structure equivalent to ARM3 of the $\mathrm{IP}_{3} \mathrm{R}$, is absent from $\mathrm{IP}_{3} \mathrm{Rs}$ (Fan et al.
2015), and nor does the EF-hand provide the essential $\mathrm{Ca}^{2+}$ regulation of RyRs (Guo et al. 2016). Hence, the conserved $\mathrm{Ca}^{2+}$-binding site at the interface between the cytosolic (ARM3) and channel domains (LNK) suggests an appealing, but untested, link between $\mathrm{Ca}^{2+}$ and gating of the $\mathrm{IP}_{3} \mathrm{R}$, namely that $\mathrm{IP}_{3}$ binding stabilizes this $\mathrm{Ca}^{2+}$-binding site and $\mathrm{Ca}^{2+}$ binding to it then leads to opening of the pore. This proposal also aligns with the suggestion that the stimulatory $\mathrm{Ca}^{2+}$-binding site may be close to the pore (Vais et al. 2012). The high-resolution structure of $\mathrm{IP}_{3} \mathrm{R} 3$ recently identified another $\mathrm{Ca}^{2+}$-binding site, which is also formed by residues provided by different domains across an interface between them (ARM1 and ARM2) (Paknejad and Hite 2018). It is not yet clear how (or whether) either of these $\mathrm{Ca}^{2+}$-binding sites relates to stimulation and inhibition of $\mathrm{IP}_{3}$ Rs by cytosolic $\mathrm{Ca}^{2+}$. It is, however, intriguing that both sites are formed by residues contributed by different domains, consistent with $\mathrm{IP}_{3}$-evoked rigid-body domain movements influencing whether $\mathrm{Ca}^{2+}$ binds to the sites.

Recent progress has brought us close to seeing how $\mathrm{IP}_{3}$ binding to the IBC causes pore residues some $7 \mathrm{~nm}$ away to move and allow $\mathrm{Ca}^{2+}$ to pass from the ER lumen to the cytosol (Fan et al. 2018; Paknejad and Hite 2018). $\mathrm{IP}_{3}$ initiates $\mathrm{IP}_{3} \mathrm{R}$ activation by causing closure of the IBC. That conformational change must then pass onward through a critical nexus formed between the cytoplasmic and pore domains at the ILDLNK complex. Since $\mathrm{IP}_{3}$ primes $\mathrm{IP}_{3}$ Rs to bind $\mathrm{Ca}^{2+}$, which then triggers channel opening (Fig. 2B; Adkins and Taylor 1999), we speculate that an intervening step between $\mathrm{IP}_{3}$ binding to the IBC and pore opening involves rearrangement of $\mathrm{Ca}^{2+}$-binding sites at the ARM1-ARM2 interface or at the LNK-ARM3 nexus. The conformational changes evoked by $\mathrm{Ca}^{2+}$ binding must then pass through the ILD-LNK complex to cause movement of a hydrophobic residue in TMD6 and allow opening of the pore (Fig. 3D).

\section{IP $_{3}$ RECEPTORS AS SIGNALING HUBS}

$\mathrm{IP}_{3}$ and $\mathrm{Ca}^{2+}$ are the essential regulators of $\mathrm{IP}_{3} \mathrm{R}$ gating (Fig. 2), but many intracellular signals, 
including ATP (Wagner and Yule 2012), cAMP (Taylor 2017), $\mathrm{H}^{+}$(Worley et al. 1987), NADH (Kaplin et al. 1996), and the redox state (Joseph 2010; Joseph et al. 2018), can modulate this regulation. $\mathrm{IP}_{3}$ Rs can also be regulated by covalent modifications, including phosphorylation, controlled by more than a dozen protein kinases and phosphatases, ubiquitination (Wojcikiewicz 2018), transglutaminase-mediated crosslinking of Gln-Lys residues (Hamada et al. 2014), and perhaps nitrosylation (Pan et al. 2008). Proteolysis of $\mathrm{IP}_{3}$ Rs by caspase-3 (Hirota et al. 1999) or calpains (Magnusson et al. 1993) may contribute to their degradation. But after limited proteolysis, $\mathrm{IP}_{3} \mathrm{R}$ fragments remain associated as a functional channel. Intriguingly, native and cleaved $\mathrm{IP}_{3} \mathrm{Rs}$ respond differently, suggesting that proteolysis can provide more subtle regulation than merely down-regulating $\mathrm{IP}_{3}$ Rs (Alzayady et al. 2013; Wang et al. 2017).

More impressive still is the huge array of proteins that associate with $\mathrm{IP}_{3}$ Rs (Fig. 4A; Prole and Taylor 2016). These proteins, which may associate with cytosolic or luminal parts of the $\mathrm{IP}_{3} \mathrm{R}$, can regulate the distribution of $\mathrm{IP}_{3} \mathrm{Rs}$ (Geyer et al. 2015), their affiliation with signaling pathways that deliver $\mathrm{IP}_{3}$ ( $\mathrm{Tu}$ et al. 1998) or cAMP (Tovey et al. 2008) to $\mathrm{IP}_{3} \mathrm{Rs}$, the sensitivity of $\mathrm{Ca}^{2+}$ release to $\mathrm{IP}_{3}$ and $\mathrm{Ca}^{2+}$, and they may allow $\mathrm{IP}_{3} \mathrm{Rs}$ to deliver $\mathrm{Ca}^{2+}$ to specific decoding proteins (Fig. 4B; Szabadkai et al. 2006). Many of these modulatory influences are likely to be context specific, determined, for example, by $\mathrm{IP}_{3} \mathrm{R}$ subtype, cell type, and perhaps contingent on interactions between modulators (Ivanova et al. 2014; Prole and Taylor 2016). $\mathrm{IP}_{3} \mathrm{R}$-binding protein released with $\mathrm{IP}_{3}$ (IRBIT), for example, is a protein that competes with $\mathrm{IP}_{3}$ for binding to the IBC, but it does so only after IRBIT phosphorylation (Ando et al. 2014).

Modulatory proteins also provide links between $\mathrm{IP}_{3} \mathrm{Rs}$ and human diseases, additional to those arising from loss or mutation of $\mathrm{IP}_{3} \mathrm{Rs}$ (Berridge 2016; Casey et al. 2017; Hisatsune and Mikoshiba 2017; Terry et al. 2018). The mutant forms of Huntingtin associated with Huntington's disease, mutant ataxins associated with spinocerebellar ataxias, and mutant presenilins associated with inherited forms of Alzheimer's disease, for example, have each been reported to enhance $\mathrm{IP}_{3}$-evoked $\mathrm{Ca}^{2+}$ signals (Chen et al. 2008; Cheung et al. 2008, 2010; Liu et al. 2009; Egorova and Bezprozvanny 2018).

$\mathrm{IP}_{3} \mathrm{R}$-evoked $\mathrm{Ca}^{2+}$ signals may also be targets for cancer therapeutics (Vervloessem et al. 2018). Transfer of $\mathrm{Ca}^{2+}$ from the ER to mitochondria via $\mathrm{IP}_{3}$ Rs stimulates mitochondrial ATP production, but excessive $\mathrm{Ca}^{2+}$ transfer triggers apoptosis (Cardenas et al.2010). ER-mitochondria $\mathrm{Ca}^{2+}$ transfer can thereby promote cell survival or death, according to the magnitude of the transfer. It has been suggested that tumor cells are "addicted" to ER-mitochondria $\mathrm{Ca}^{2+}$ transfer and so particularly susceptible to its inhibition because they lack the robust, protective autophagy response of normal cells (Cardenas et al. 2016). Here, inhibition of $\mathrm{Ca}^{2+}$ transfer to mitochondria might provide an opportunity to selectively kill cancer cells by necrosis (Cardenas et al. 2016). Conversely, exaggerating the transfer of $\mathrm{Ca}^{2+}$ from ER to mitochondria can trigger apoptosis. The tumor suppressors, Bap1 (Bononi et al. 2013) and PTEN (Kuchay et al. 2017), achieve this by protecting $\mathrm{IP}_{3} \mathrm{Rs}$ from proteosomal degradation, allowing sustained $\mathrm{Ca}^{2+}$ transfer to mitochondria and enhanced sensitivity to stimuli that promote apoptosis. The proapoptotic protein, Bok, achieves the same effect by protecting $\mathrm{IP}_{3} \mathrm{Rs}$ from cleavage by caspase (Schulman et al. 2013). Other anti-apoptotic members of the Bcl-2 family of proteins (e.g., Bcl-2, Bcl-XL) are also proposed to influence ER-mitochondrial $\mathrm{Ca}^{2+}$ transfer, and thereby apoptosis, but by regulating the activity, rather than the expression, of $\mathrm{IP}_{3} \mathrm{Rs}$ (discussed in Vervloessem et al. 2018). These interactions are now attracting interest as potential therapeutic targets in cancer.

Most accessory proteins that affect $\mathrm{IP}_{3^{-}}$ evoked $\mathrm{Ca}^{2+}$ release appear to do so indirectly by influencing $\mathrm{IP}_{3}$ or $\mathrm{Ca}^{2+}$ binding or the interplay between them. However, a few proteins, including $\mathrm{G} \beta \gamma$, which may mimic $\mathrm{IP}_{3}$ (Zeng et al. 2003), and the $\mathrm{Ca}^{2+}$-binding proteins, CIB1 $\left(\mathrm{Ca}^{2+}-\right.$ and integrin-binding protein) (White et al. 2006) and CaBP1 (Yang et al. 2002), have been claimed to reversibly gate $\mathrm{IP}_{3} \mathrm{Rs}$ directly, bypassing the need for $\mathrm{IP}_{3}$. However, the sugges- 
A

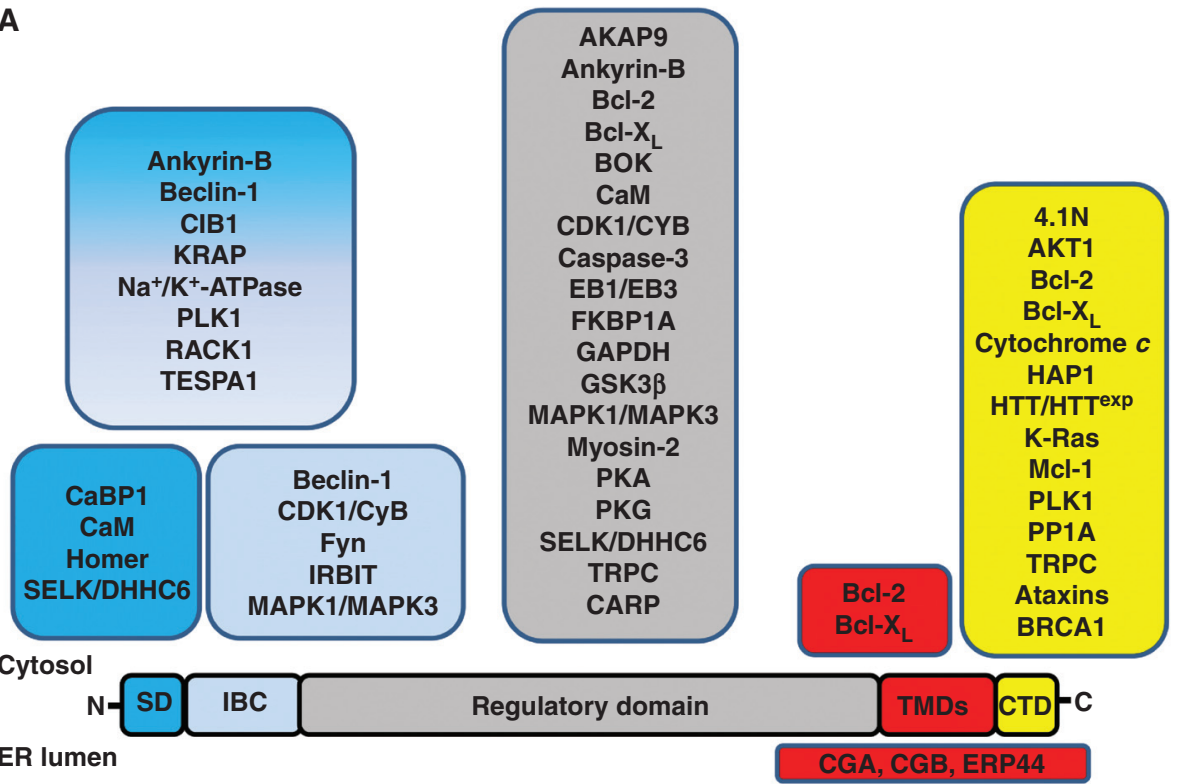

B

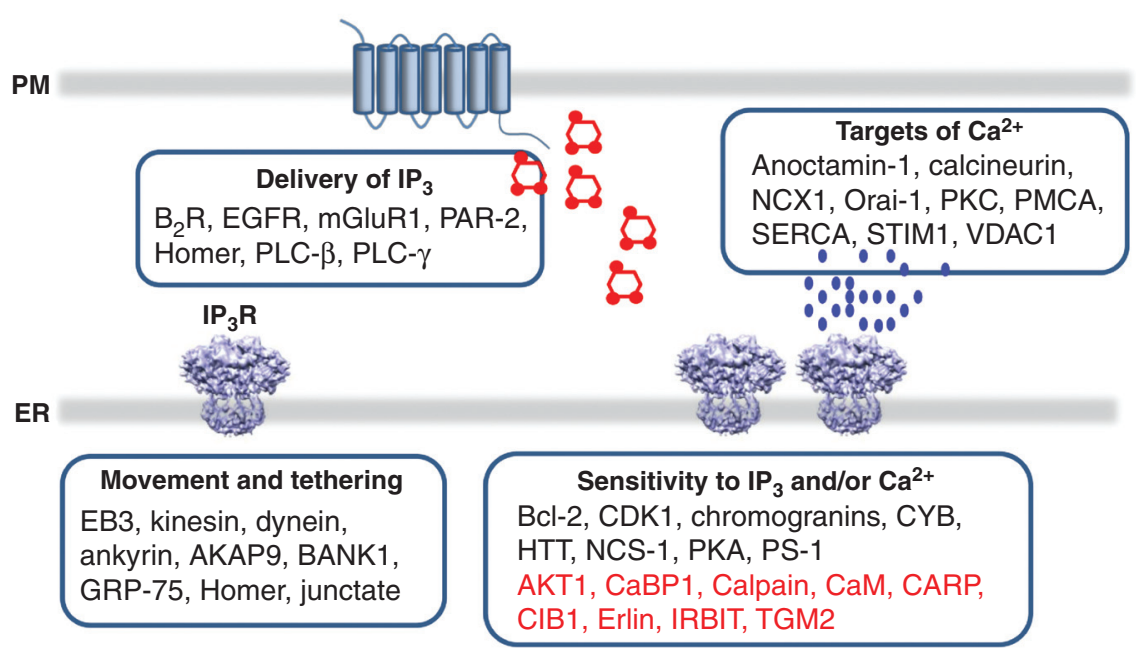

Figure 4. $\mathrm{IP}_{3}$ receptors interact with many accessory proteins. $(A)$ Proteins that interact with $\mathrm{IP}_{3} \mathrm{Rs}$ shown according to the regions of the $\mathrm{IP}_{3} \mathrm{R}$ with which they interact. (From Prole and Taylor 2016; adapted under the terms of the Creative Commons Attribution License [CC BY, 2016].) AKAP9, A-kinase anchoring protein 9; AKT1, RAC- $\alpha$ serine/threonine protein kinase; BANK1, B-cell scaffold protein with ankyrin repeats; Bcl-2, B-cell lymphoma $2 ; \mathrm{B}_{2} \mathrm{R}$, bradykinin $\mathrm{B}_{2}$ receptor; $\mathrm{BRCA} 1$, breast and ovarian cancer susceptibility gene 1 ; $\mathrm{CaBP} 1, \mathrm{Ca}^{2+}$ binding protein 1; CaM, calmodulin; CARP, carbonic anhydrase-related protein; CDK1, cyclin-dependent kinase 1; CIB1, $\mathrm{Ca}^{2+}$ - and integrin-binding protein 1; CYB, cyclin-B1; EB3, end-binding protein 3; EGFR, epidermal growth factor receptor; GRP-75, glucose-regulated protein 75; HTT, huntingtin; IRBIT, $\mathrm{IP}_{3}$-binding protein released with $\mathrm{IP}_{3}$; mGluR1, metabotropic glutamate receptor 1 ; NCS-1, neuronal $\mathrm{Ca}^{2+}$-sensor 1; PAR-2, protease-activated receptor 2; PKA, protein kinase A; PLC- $\beta$, phospholipase C $\beta$; PLC- $\gamma$, phospholipase C $\gamma$, PS-1/PS-2, presenilin 1/2; NCX1, $\mathrm{Na}^{+} / \mathrm{Ca}^{2+}$ exchanger 1; PKC, protein kinase C; PMCA, plasma membrane $\mathrm{Ca}^{2+}$-ATPase; SERCA, sarco/endoplasmic reticulum $\mathrm{Ca}^{2+}$-ATPase; STIM1, stromal interaction molecule 1; TGM2, transglutaminase-2; VDAC1, voltage-dependent anion channel 1. Proteins shown in red inhibit the activity of $\mathrm{IP}_{3}$ Rs. Original sources for additional interactions shown here are ataxins (Chen et al. 2008; Liu et al. 2009), CARP (Hirota et al. 2003), and BRCA1 (Hedgepeth et al. 2015). (B) Examples of proteins shown according to whether they facilitate delivery of $\mathrm{IP}_{3}$ to $\mathrm{IP}_{3} \mathrm{Rs}$, intracellular distribution of $\mathrm{IP}_{3} \mathrm{Rs}, \mathrm{IP}_{3} \mathrm{R}$ activation or delivery of $\mathrm{Ca}^{2+}$ to specific targets. 
D.L. Prole and C.W. Taylor

tion that CaBP1 stimulates $\mathrm{IP}_{3}$ Rs has been challenged by three different groups (Haynes et al. 2004; Nadif Kasri et al. 2004; Li et al. 2013). There is a need to establish whether there are additional physiological means, other than through $\mathrm{IP}_{3}$ and $\mathrm{Ca}^{2+}$, to stimulate $\mathrm{IP}_{3} \mathrm{R}$ activation.

We need also to consider whether the scaffolding of signaling proteins by $\mathrm{IP}_{3} \mathrm{Rs}$ serves only to funnel information toward an $\mathrm{IP}_{3}$ evoked $\mathrm{Ca}^{2+}$ signal, or might these scaffolds fulfil additional, and possibly unrelated, roles. There is, for example, evidence that $\mathrm{IP}_{3} \mathrm{Rs}$, independent of their ability to release $\mathrm{Ca}^{2+}$ from the ER, can modulate SOCE (Chakraborty et al. 2016) and, since the mechanisms are not yet clear (Thillaiappan et al. 2019), they may arise through scaffolding of proteins by $\mathrm{IP}_{3} \mathrm{Rs}$.

Space limitations forbid comprehensive discussion of $\mathrm{IP}_{3}$ Rs and their accessory proteins (additional examples can be found in Prole and Taylor 2016). Instead, we show some of the proteins that intercede at different levels, from facilitating delivery of $\mathrm{IP}_{3}$ to $\mathrm{IP}_{3} \mathrm{Rs}$ to guiding presentation of their $\mathrm{Ca}^{2+}$ signals to specific targets (Fig. 4B). A clear theme is that assembly of signaling proteins around $\mathrm{IP}_{3} \mathrm{Rs}$ provides many opportunities for local integration and processing of information, before it is returned to the cell as a $\mathrm{Ca}^{2+}$ signal.

\section{LICENSING IP ${ }_{3}$ RECEPTORS TO RESPOND}

High-resolution optical microscopy with fluorescent $\mathrm{Ca}^{2+}$ indicators has revealed the subcellular organization of the $\mathrm{Ca}^{2+}$ signals evoked by $\mathrm{IP}_{3}$. Since these recordings have succeeded in observing the openings of single $\mathrm{IP}_{3} \mathrm{Rs}$ in situ, they have been aptly named "optical patchclamp" recording (Parker and Smith 2010). The results of these analyses show that low concentrations of $\mathrm{IP}_{3}$ evoke short-lived openings of single $\mathrm{IP}_{3} \mathrm{Rs}$ ("Ca ${ }^{2+}$ blips"). Greater concentrations of $\mathrm{IP}_{3}$ evoke "Ca ${ }^{2+}$ puffs," which typically last $\sim 100 \mathrm{msec}$ and report the coordinated opening of a few $\mathrm{IP}_{3} \mathrm{Rs}$ within a small cluster. These are thought to arise when $\mathrm{Ca}^{2+}$ released by one $\mathrm{IP}_{3} \mathrm{R}$ rapidly ignites the activity of its $\mathrm{IP}_{3}$-bound neighbors through CICR (Fig. 2C; Smith and Parker 2009). $\mathrm{Ca}^{2+}$ puffs may be the building blocks of all $\mathrm{IP}_{3}$-evoked $\mathrm{Ca}^{2+}$ signals because all three $\mathrm{IP}_{3} \mathrm{R}$ subtypes can generate $\mathrm{Ca}^{2+}$ puffs with broadly similar properties (Mataragka and Taylor 2018). As stimulus intensities increase further, $\mathrm{Ca}^{2+}$ diffusing from one $\mathrm{Ca}^{2+}$ puff can recruit the activity of a more distant site, generating a regenerative $\mathrm{Ca}^{2+}$ wave that spreads across the cell (Rooney et al. 1990; Bootman et al. 1997; Marchant et al. 1999). Further increases in stimulus intensity increase the frequency of the $\mathrm{Ca}^{2+}$ waves. These are manifest as $\mathrm{Ca}^{2+}$ spikes or oscillations at the whole-cell level, as first reported by Peter Cobbold (Woods et al. 1986). Hence, both the spatial and temporal organization of cytosolic $\mathrm{Ca}^{2+}$ signals changes with stimulus intensity, and this has important functional consequences (Thurley et al. 2014; Samanta and Parekh 2017). It is immediately apparent that both the coregulation of $\mathrm{IP}_{3} \mathrm{Rs}$ by $\mathrm{Ca}^{2+}$ and $\mathrm{IP}_{3}$, and the geographical relationships between $\mathrm{IP}_{3} \mathrm{Rs}$, are important determinants of how far $\mathrm{Ca}^{2+}$ signals progress through this hierarchy of $\mathrm{Ca}^{2+}$ release events (Fig. 2).

Considerable evidence suggests that most $\mathrm{IP}_{3}$ Rs are mobile within ER membranes (Ferreri-Jacobia et al. 2005; Fukatsu et al. 2010; Pantazaka and Taylor 2011; Smith et al. 2014; Thillaiappan et al. 2017) and that $\mathrm{IP}_{3}$ and/or $\mathrm{Ca}^{2+}$ can regulate clustering of $\mathrm{IP}_{3} \mathrm{Rs}$ (Wilson et al. 1998; Iwai et al. 2005; Tateishi et al. 2005; Chalmers et al. 2006; Tojyo et al. 2008; Rahman and Taylor 2009; Pantazaka and Taylor 2011). There is also evidence that clustering may be required for cells to generate effective $\mathrm{Ca}^{2+}$ signals (Geyer et al. 2015). There is, however, a conundrum because, whereas most $\mathrm{IP}_{3} \mathrm{Rs}$ are mobile, the $\mathrm{Ca}^{2+}$ puffs evoked by $\mathrm{IP}_{3}$ repeatedly initiate at the same fixed sites within a cell (Thomas et al. 1998; Smith and Parker 2009; Smith et al. 2009b; Keebler and Taylor 2017; Mataragka and Taylor 2018). Why should a small fraction of the $\mathrm{IP}_{3} \mathrm{Rs}$ in a cell assume complete responsibility for generating $\mathrm{Ca}^{2+}$ puffs?

We recently addressed this problem using HeLa cells in which gene editing was used to tag endogenous $\mathrm{IP}_{3} \mathrm{R} 1$ with EGFP so that we could simultaneously observe the distribution of $\mathrm{IP}_{3} \mathrm{Rs}$ and the $\mathrm{Ca}^{2+}$ signals they evoke (Thillaiappan et al. 2017). The results show that most 
$\mathrm{IP}_{3}$ Receptors

$\mathrm{IP}_{3} \mathrm{Rs}$ are assembled into small clusters or puncta, and while the number of $\mathrm{IP}_{3} \mathrm{Rs}$ within each cluster varies considerably, there is an average of $\sim 8 \mathrm{IP}_{3} \mathrm{Rs}$ per cluster. Super-resolution imaging reveals that although $\mathrm{IP}_{3} \mathrm{Rs}$ remain within their puncta, they are often too far apart $(>100 \mathrm{~nm})$ for the $\mathrm{IP}_{3}$ Rs to be held together by direct interactions between them (Fig. 5A,B). Instead, we suggest that a scaffold, which may be formed by proteins or lipids, corrals $\mathrm{IP}_{3} \mathrm{Rs}$ into puncta (Fig. 5C). The scaffold has yet to be identified. Most $\mathrm{IP}_{3} \mathrm{R}$ puncta, which are present in ER throughout the cell, are mobile $(>70 \%)$. Most $\mathrm{IP}_{3} \mathrm{Rs}$ move by diffusion in ER membranes, but a small faction is moved directionally by microtubule motors. Others have shown (Smith et al. 2009a; Ellefsen and Parker 2018), and we have confirmed (Keebler and Taylor 2017; Thillaiappan et al. 2017), that although $\mathrm{IP}_{3} \mathrm{Rs}$ are present throughout the cell, almost all $\mathrm{Ca}^{2+}$ puffs arise from $\mathrm{IP}_{3} \mathrm{Rs}$ within ER that lies close to the PM. This occurs whether $\mathrm{IP}_{3}$ is delivered to the cell through endogenous receptor-activated signaling pathways, which might locally deliver $\mathrm{IP}_{3}$ immediately beneath the $\mathrm{PM}$, or by flash-photolysis of caged- $\mathrm{IP}_{3}$, which uniformly delivers $\mathrm{IP}_{3}$ throughout the cell. Hence, the propensity of near-PM IP ${ }_{3}$ Rs to respond does not arise from selective delivery of $\mathrm{IP}_{3}$. Indeed, exactly the same $\mathrm{Ca}^{2+}$ release sites respond after photolysis of caged- $\mathrm{IP}_{3}$ or stimulation of endogenous signaling pathways
A

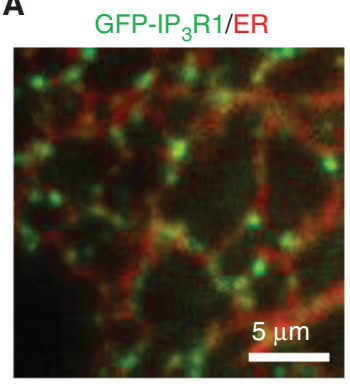

B

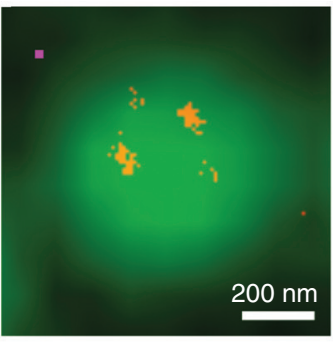

D

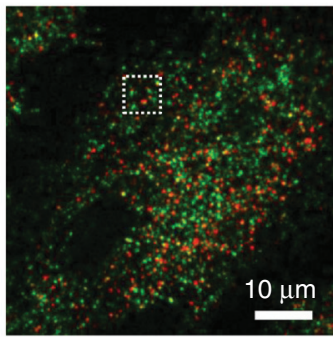

GFP-IP ${ }_{3} R 1 / S T I M 1$

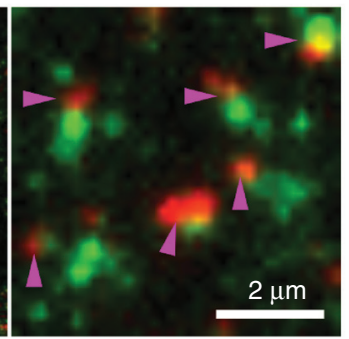

C

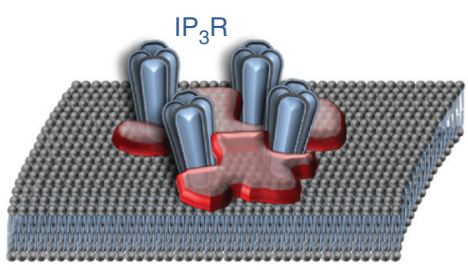

E
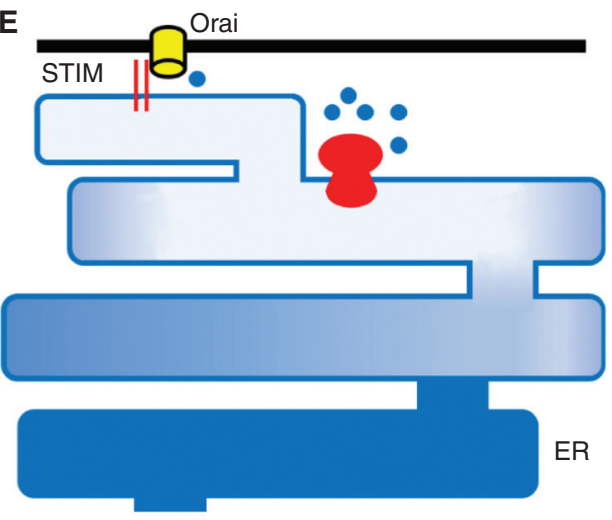

Figure 5. Immobile $\mathrm{IP}_{3}$ receptor clusters initiate $\mathrm{Ca}^{2+}$ signals. (A) HeLa cells with endogenous $\mathrm{IP}_{3} \mathrm{R} 1$ tagged with EGFP showing $\mathrm{IP}_{3} \mathrm{R}$ puncta (green) within endoplasmic reticulum (ER) membranes (red). (B) Diffractionlimited image of a punctum recorded using total internal reflection fluorescence (TIRF) microscopy, and the superimposed super-resolution (STORM) image showing $\mathrm{IP}_{3} \mathrm{Rs}$ (red) within the punctum. The magenta square indicates the approximate size of a single tetrameric $\mathrm{IP}_{3} \mathrm{R}$. $(C) \mathrm{IP}_{3} \mathrm{Rs}$ appear to be diffusively distributed within a punctum, suggesting the need for a scaffold to corral $\mathrm{IP}_{3}$ Rs. $(D)$ TIRF images of a HeLa cell in which the ER has been depleted of $\mathrm{Ca}^{2+}$ by treatment with thapsigargin, showing the distribution of STIM1 (red) and IP ${ }_{3} \mathrm{R}$ (green). The enlarged image shows that stromal interaction molecule (STIM) puncta form alongside the ER where the immobile $\mathrm{IP}_{3} \mathrm{Rs}$ that are licensed to respond are parked. (Data results for $A-D$ are from Thillaiappan et al. 2017.) (E) Licensed $\mathrm{IP}_{3}$ Rs parked alongside the ER-PM junctions where store-operated $\mathrm{Ca}^{2+}$ entry (SOCE) occurs may allow substantial loss of $\mathrm{Ca}^{2+}$ from that part of the ER without causing appreciable $\mathrm{Ca}^{2+}$ loss from the remaining ER. The ER-PM junction with its associated licensed $\mathrm{IP}_{3}$ Rs may constitute the basic functional unit for SOCE. 
(Keebler and Taylor 2017; Lock et al. 2017). Furthermore, it is only the immobile $\mathrm{IP}_{3} \mathrm{R}$ puncta adjacent to the PM that initiate $\mathrm{Ca}^{2+}$ puffs (Thillaiappan et al. 2017). It is, therefore, only a small fraction of the several thousand $\mathrm{IP}_{3}$ Rs expressed in a cell that are competent, or "licensed," to respond. It will be important to identify the factor that licenses this small cohort of $\mathrm{IP}_{3} \mathrm{Rs}$ to respond to $\mathrm{IP}_{3}$.

We noted in a preceding section that $\mathrm{IP}_{3} \mathrm{R}$ activation and SOCE are an almost universal partnership (Fig. 1B). It is, therefore, intriguing that the ER-PM junctions where STIM1 accumulates after loss of $\mathrm{Ca}^{2+}$ from the ER sit alongside the sites where licensed $\mathrm{IP}_{3} \mathrm{Rs}$ reside (Fig. 5D; Thillaiappan et al. 2017). This too may have functional consequences by allowing active $\mathrm{IP}_{3}$ Rs to locally and substantially deplete ER specifically located alongside ER-PM junctions. This provides a possible answer to another problem, namely, that $\mathrm{Ca}^{2+}$ within the ER lumen has many roles beyond $\mathrm{Ca}^{2+}$ signaling-it is required for protein folding, for example-yet STIM1 is activated only after substantial loss of $\mathrm{Ca}^{2+}$ from the ER (Brandman et al. 2007; Luik et al. 2008; Bird et al. 2009). How does the ER regulate SOCE without compromising its other functions? We suggest that licensed $\mathrm{IP}_{3}$ Rs held alongside ER$\mathrm{PM}$ junctions may be the basic functional units of SOCE, allowing $\mathrm{IP}_{3}$ to cause a substantial loss of $\mathrm{Ca}^{2+}$ from the ER that regulates SOCE without trespassing into the remaining ER (Fig. 5E; Thillaiappan et al. 2017, 2019; Taylor and Machaca 2019).

\section{CONCLUDING REMARKS}

$\mathrm{IP}_{3} \mathrm{Rs}$ allow $\mathrm{Ca}^{2+}$ to be redistributed, in response to receptor activation, from the ER lumen to the cytosol or other organelles, and they ultimately control SOCE. Coregulation of $\mathrm{IP}_{3} \mathrm{Rs}$ by $\mathrm{IP}_{3}$ and $\mathrm{Ca}^{2+}$ endows $\mathrm{IP}_{3} \mathrm{Rs}$ with a capacity to mediate regenerative $\mathrm{Ca}^{2+}$ signals, which give rise to a hierarchy of $\mathrm{Ca}^{2+}$-release events as stimulus intensities increase. Recent progress with x-ray crystallography and cryo-EM have brought us closer to understanding how $\mathrm{IP}_{3}$ binding to a site located some $7 \mathrm{~nm}$ from the pore, triggers $\mathrm{Ca}^{2+}$ binding and thence opening of the pore.
High-resolution measurements of $\mathrm{Ca}^{2+}$ signals in living cells have revealed that only a small cohort of immobile $\mathrm{IP}_{3} \mathrm{R}$ clusters, parked alongside the ER-PM junctions where SOCE occurs, are licensed to respond. These $\mathrm{IP}_{3} \mathrm{Rs}$ both mediate $\mathrm{Ca}^{2+}$ puffs and they may selectively regulate SOCE.

\section{ACKNOWLEDGMENTS}

Work from the authors' laboratory is supported by the Biotechnology and Biological Sciences Research Council UK (Grant No. BB/P005330/ 1 to C.W.T.) and the Wellcome Trust (Grant No. 101844 to C.W.T.).

\section{REFERENCES}

Adkins CE, Taylor CW. 1999. Lateral inhibition of inositol 1,4,5-trisphosphate receptors by cytosolic $\mathrm{Ca}^{2+}$. Curr Biol 9: 1115-1118. doi:10.1016/S0960-9822(99)80481-3

Allbritton NL, Meyer T, Stryer L. 1992. Range of messenger action of calcium ion and inositol 1,4,5-trisphosphate. Science 258: 1812-1815. doi:10.1126/science.1465619

Alzayady KJ, Chandrasekhar R, Yule DI. 2013. Fragmented inositol 1,4,5-trisphosphate receptors retain tetrameric architecture and form functional $\mathrm{Ca}^{2+}$ release channels. J Biol Chem 288: 11122-11134. doi:10.1074/jbc.M113. 453241

Alzayady KJ, Sebe-Pedros A, Chandrasekhar R, Wang L, Ruiz-Trillo I, Yule DI. 2015. Tracing the evolutionary history of inositol, 1, 4, 5-trisphosphate receptor: Insights from analyses of Capsaspora owczarzaki $\mathrm{Ca}^{2+}$ release channel orthologs. Mol Biol Evol 32: 2236-2253. doi: 10.1093/molbev/msv098

Alzayady KJ, Wang L, Chandrasekhar R, Wagner LE II, Van Petegem F, Yule DI. 2016. Defining the stoichiometry of inositol 1,4,5-trisphosphate binding required to initiate $\mathrm{Ca}^{2+}$ release. Sci Signal 9: ra35. doi:10.1126/scisignal. aad6281

Amador FJ, Liu S, Ishiyama N, Plevin MJ, Wilson A, Maclennan DH, Ikura M. 2009. Crystal structure of type I ryanodine receptor amino-terminal $\beta$-trefoil domain reveals a disease-associated mutation "hot spot" loop. Proc Natl Acad Sci 106: 11040-11044. doi:10.1073/pnas. 0905186106

Ando H, Kawaai K, Mikoshiba K. 2014. IRBIT: A regulator of ion channels and ion transporters. Biochim Biophys Acta 1843: 2195-2204. doi:10.1016/j.bbamcr.2014.01.031

Atakpa P, Thillaiappan NB, Mataragka S, Prole DL, Taylor CW. 2018. $\mathrm{IP}_{3}$ receptors preferentially associate with ER-lysosome contact sites and selectively deliver $\mathrm{Ca}^{2+}$ to lysosomes. Cell Rep 25: 3180-3193. doi:10.1016/j. celrep.2018.11.064

Bading H. 2013. Nuclear calcium signalling in the regulation of brain function. Nat Rev Neurosci 14: 593-608. doi: $10.1038 /$ nrn353 
Berridge MJ. 1993. Inositol trisphosphate and calcium signalling. Nature 361: 315-325. doi:10.1038/361315a0

Berridge MJ. 2005. Unlocking the secrets of cell signaling. Annu Rev Physiol 67: 1-21. doi:10.1146/annurev. physiol.67.040103.152647

Berridge MJ. 2016. The inositol trisphosphate/calcium signaling pathway in health and disease. Physiol Rev 96: 1261-1296. doi:10.1152/physrev.00006.2016

Bezprozvanny I, Watras J, Ehrlich BE. 1991. Bell-shaped calcium-response curves of Ins $(1,4,5) \mathrm{P}_{3^{-}}$and calciumgated channels from endoplasmic reticulum of cerebellum. Nature 351: 751-754. doi:10.1038/351751a0

Bird GS, Hwang SY, Smyth JT, Fukushima M, Boyles RR, Putney JW Jr. 2009. STIM1 is a calcium sensor specialized for digital signaling. Curr Biol 19: 1724-1729. doi:10.1016/ j.cub.2009.08.022

Bononi A, Bonora M, Marchi S, Missiroli S, Poletti F, Giorgi C, Pandolfi PP, Pinton P. 2013. Identification of PTEN at the ER and MAMs and its regulation of $\mathrm{Ca}^{2+}$ signaling and apoptosis in a protein phosphatase-dependent manner. Cell Death Differ 20: 1631-1643. doi:10.1038/cdd. 2013.77

Bootman MD, Berridge MJ, Lipp P. 1997. Cooking with calcium: The recipes for composing global signals from elementary events. Cell 91: 367-373. doi:10.1016/S00928674(00)80420-1

Bosanac I, Alattia JR, Mal TK, Chan J, Talarico S, Tong FK, Tong KI, Yoshikawa F, Furuichi T, Iwai M, et al. 2002. Structure of the inositol 1,4,5-trisphosphate receptor binding core in complex with its ligand. Nature 420: 696-700. doi:10.1038/nature01268

Bosanac I, Yamazaki H, Matsu-ura T, Michikawa T, Mikoshiba K, Ikura M. 2005. Crystal structure of the ligand binding suppressor domain of type 1 inositol 1,4,5-trisphosphate receptor. Mol Cell 17: 193-203. doi:10.1016/j. molcel.2004.11.047

Brandman O, Liou J, Park WS, Meyer T. 2007. STIM2 is a feedback regulator that stabilizes basal cytosolic and endoplasmic reticulum $\mathrm{Ca}^{2+}$ levels. Cell 131: 1327-1339. doi:10.1016/j.cell.2007.11.039

Cardenas C, Miller RA, Smith I, Bui T, Molgo J, Muller M, Vais H, Cheung KH, Yang J, Parker I, et al. 2010. Essential regulation of cell bioenergetics by constitutive $\mathrm{InsP}_{3}$ receptor $\mathrm{Ca}^{2+}$ transfer to mitochondria. Cell 142: 270-283. doi:10.1016/j.cell.2010.06.007

Cardenas C, Muller M, McNeal A, Lovy A, Jana F, Bustos G, Urra F, Smith N, Molgo J, Diehl JA, et al. 2016. Selective vulnerability of cancer cells by inhibition of $\mathrm{Ca}^{2+}$ transfer from endoplasmic reticulum to mitochondria. Cell Rep 14: 2313-2324. doi:10.1016/j.celrep.2016.02.030

Casey JP, Hirouchi T, Hisatsune C, Lynch B, Murphy R, Dunne AM, Miyamoto A, Ennis S, van der Spek N, O’Hici $\mathrm{B}$, et al. 2017. A novel gain-of-function mutation in the ITPR1 suppressor domain causes spinocerebellar ataxia with altered $\mathrm{Ca}^{2+}$ signal patterns. J Neurol 264: $1444-$ 1453. doi:10.1007/s00415-017-8545-5

Chakraborty S, Deb BK, Chorna T, Konieczny V, Taylor CW, Hasan G. 2016. Mutant $\mathrm{IP}_{3}$ receptors attenuate storeoperated $\mathrm{Ca}^{2+}$ entry by destabilizing STIM-Orai interactions in Drosophila neurons. J Cell Sci 129: 3903-3910. doi:10.1242/jcs.191585
Chalmers M, Schell MJ, Thorn P. 2006. Agonist-evoked inositol trisphosphate receptor $\left(\mathrm{IP}_{3} \mathrm{R}\right)$ clustering is not dependent on changes in the structure of the endoplasmic reticulum. Biochem J 394: 57-66. doi:10.1042/ BJ20051130

Chen X, Tang TS, Tu H, Nelson O, Pook M, Hammer R, Nukina N, Bezprozvanny I. 2008. Deranged calcium signaling and neurodegeneration in spinocerebellar ataxia type 3. J Neurosci 28: 12713-12724. doi:10.1523/ jneurosci.3909-08.2008

Cheung KH, Shineman D, Muller M, Cardenas C, Mei L, Yang J, Tomita T, Iwatsubo T, Lee VM, Foskett JK. 2008. Mechanism of $\mathrm{Ca}^{2+}$ disruption in Alzheimer's disease by presenilin regulation of $\mathrm{InsP}_{3}$ receptor channel gating. Neuron 58: 871-883. doi:10.1016/j.neuron.2008.04.015

Cheung KH, Mei L, Mak DO, Hayashi I, Iwatsubo T, Kang DE, Foskett JK. 2010. Gain-of-function enhancement of $\mathrm{IP}_{3}$ receptor modal gating by familial Alzheimer's disease-linked presenilin mutants in human cells and mouse neurons. Sci Signal 3: ra22. doi:10.1126/scisignal.2000818

Csordas G, Weaver D, Hajnoczky G. 2018. Endoplasmic reticular-mitochondrial contactology: Structure and signaling functions. Trends Cell Biol 28: 523-540. doi: 10.1016/j.tcb.2018.02.009

des Georges A, Clarke OB, Zalk R, Yuan Q, Condon KJ, Grassucci RA, Hendrickson WA, Marks AR, Frank J. 2016. Structural basis for gating and activation of RyR1. Cell 167: 145-157.e17. doi:10.1016/j.cell.2016.08.075

Dickinson GD, Ellefsen KL, Dawson SP, Pearson JE, Parker I. 2016. Hindered cytoplasmic diffusion of inositol trisphosphate restricts its cellular range of action. Sci Signal 9: ra108. doi:10.1126/scisignal.aag1625

Du GG, Maclennan DH. 1998. Functional consequences of mutations of conserved, polar amino acids in transmembrane sequences of the $\mathrm{Ca}^{2+}$ release channel (ryanodine receptor) of rabbit skeletal muscle sarcoplasmic reticulum. J Biol Chem 273: 31867-31872. doi:10.1074/jbc. 273.48.31867

Echevarría W, Leite MF, Guerra MT, Zipfel WR, Nathanson MH. 2003. Regulation of calcium signals in the nucleus by a nucleoplasmic reticulum. Nat Cell Biol 5: 440-446. doi:10.1038/ncb980

Efremov RG, Leitner A, Aebersold R, Raunser S. 2015. Architecture and conformational switch mechanism of the ryanodine receptor. Nature 517: 39-43. doi:10.1038/ nature13916

Egorova PA, Bezprozvanny I. 2018. Inositol 1,4,5-trisphosphate receptors and neurodegenerative disorders. FEBS $J$ 285: 3547-3565. doi:10.1111/febs.14366

Ellefsen KL, Parker I. 2018. Dynamic $\mathrm{Ca}^{2+}$ imaging with a simplified lattice light-sheet microscope: A sideways view of subcellular $\mathrm{Ca}^{2+}$ puffs. Cell Calcium 71: 34-44. doi: 10.1016/j.ceca.2017.11.005

Fan G, Baker ML, Wang Z, Baker MR, Sinyagovskiy PA, Chiu W, Ludtke SJ, Serysheva II. 2015. Gating machinery of InsP ${ }_{3} \mathrm{R}$ channels revealed by electron cryomicroscopy. Nature 527: 336-341. doi:10.1038/nature15249

Fan G, Baker MR, Wang Z, Seryshev AB, Ludtke SJ, Baker ML, Serysheva II. 2018. Cryo-EM reveals ligand induced allostery underlying $\mathrm{Ins}_{3} \mathrm{R}$ channel gating. Cell Res 28: 1158-1170. doi:10.1038/s41422-018-0108-5 
D.L. Prole and C.W. Taylor

Ferreri-Jacobia M, Mak DOD, Foskett JK. 2005. Translational mobility of the type 3 inositol 1,4,5-trisphosphate receptor $\mathrm{Ca}^{2+}$ release channel in endoplasmic reticulum membrane. J Biol Chem 280: 3824-3831. doi:10.1074/ jbc.M409462200

Finch EA, Turner TJ, Goldin SM. 1991. Calcium as a coagonist of inositol 1,4,5-trisphosphate-induced calcium release. Science 252: 443-446. doi:10.1126/science.2017683

Foskett JK, White C, Cheung KH, Mak DO. 2007. Inositol trisphosphate receptor $\mathrm{Ca}^{2+}$ release channels. Physiol Rev 87: 593-658. doi:10.1152/physrev.00035.2006

Fukatsu K, Bannai H, Inoue T, Mikoshiba K. 2010. Lateral diffusion of inositol 1,4,5-trisphosphate receptor type 1 in Purkinje cells is regulated by calcium and actin filaments. J Neurochem 114: 1720-1733. doi:10.1111/j.1471-4159. 2010.06885.x

Futatsugi A, Nakamura T, Yamada MK, Ebisui E, Nakamura K, Uchida K, Kitaguchi T, Takahashi-Iwanaga H, Noda T, Aruga J, et al. 2005. $\mathrm{IP}_{3}$ receptor types 2 and 3 mediate exocrine secretion underlying energy metabolism. Science 309: 2232-2234. doi:10.1126/science. 1114110

Garrity AG, Wang W, Collier CM, Levey SA, Gao Q, Xu H 2016. The endoplasmic reticulum, not the $\mathrm{pH}$ gradient, drives calcium refilling of lysosomes. eLife 5: e15887. doi:10.7554/eLife.15887

Geyer M, Huang F, Sun Y, Vogel SM, Malik AB, Taylor CW, Komarova YA. 2015. Microtubule-associated protein $\mathrm{EB} 3$ regulates $\mathrm{IP}_{3}$ receptor clustering and $\mathrm{Ca}^{2+}$ signaling in endothelial cells. Cell Rep 12: 79-89. doi: 10.1016/ j.celrep.2015.06.001

Guo W, Sun B, Xiao Z, Liu Y, Wang Y, Zhang L, Wang R, Chen SR. 2016. The EF-hand $\mathrm{Ca}^{2+}$ binding domain is not required for cytosolic $\mathrm{Ca}^{2+}$ activation of the cardiac ryanodine receptor. J Biol Chem 291: 2150-2160. doi: 10.1074/jbc.M115.693325

Hamada K, Terauchi A, Nakamura K, Higo T, Nukina N, Matsumoto N, Hisatsune C, Nakamura T, Mikoshiba K. 2014. Aberrant calcium signaling by transglutaminasemediated posttranslational modification of inositol 1,4,5-trisphosphate receptors. Proc Natl Acad Sci 111: E3966-E3975. doi:10.1073/pnas.1409730111

Hamada K, Miyatake H, Terauchi A, Mikoshiba K. 2017. $\mathrm{IP}_{3}$-mediated gating mechanism of the $\mathrm{IP}_{3}$ receptor revealed by mutagenesis and X-ray crystallography. Proc Natl Acad Sci 114: 4661-4666. doi:10.1073/pnas. 1701420114

Haynes LP, Tepikin AV, Burgoyne RD. 2004. Calcium-binding protein 1 is an inhibitor of agonist-evoked, inositol 1,4,5-trisphosphate-mediated calcium signaling. J Biol Chem 279: 547-555. doi:10.1074/jbc.M309617200

Hedgepeth SC, Garcia MI, Wagner LE II, Rodriguez AM, Chintapalli SV, Snyder RR, Hankins GD, Henderson BR, Brodie KM, Yule DI, et al. 2015. The BRCA1 tumor suppressor binds to inositol 1,4,5-trisphosphate receptors to stimulate apoptotic calcium release. J Biol Chem 290: 7304-7313. doi:10.1074/jbc.M114.611186

Hirota J, Furuichi T, Mikoshiba K. 1999. Inositol 1,4,5-trisphosphate receptor type 1 is a substrate for caspase- 3 and is cleaved during apoptosis in a caspase-3-dependent manner. J Biol Chem 274: 34433-34437. doi:10.1074/ jbc.274.48.34433
Hirota J, Ando H, Hamada K, Mikoshiba K. 2003. Carbonic anhydrase-related protein is a novel binding protein for inositol 1,4,5-trisphosphate receptor type 1 . Biochem J 372: 435-441. doi:10.1042/bj20030110

Hisatsune C, Mikoshiba K. 2017. IP $_{3}$ receptor mutations and brain diseases in human and rodents. J Neurochem 141: 790-807. doi:10.1111/jnc.13991

Hou X, Pedi L, Diver MM, Long SB. 2012. Crystal structure of the calcium release-activated calcium channel Orai. Science 338: 1308-1313. doi:10.1126/science. 1228757

Iino M. 1990. Biphasic $\mathrm{Ca}^{2+}$ dependence of inositol 1,4,5trisphosphate-induced $\mathrm{Ca}^{2+}$ release in smooth muscle cells of the guinea pig taenia caeci. J Gen Physiol 95: 1103-1122. doi:10.1085/jgp.95.6.1103

Irvine RF. 1990. "Quantal" $\mathrm{Ca}^{2+}$ release and the control of $\mathrm{Ca}^{2+}$ entry by inositol phosphates-A possible mechanism. FEBS Lett 263: 5-9. doi:10.1016/0014-5793(90) 80692-C

Ivanova $\mathrm{H}$, Vervliet $\mathrm{T}$, Missiaen L, Parys JB, De Smedt $\mathrm{H}$, Bultynck G. 2014. Inositol 1,4,5-trisphosphate receptorisoform diversity in cell death and survival. Biochim Biophys Acta 1843: 2164-2183. doi:10.1016/j.bbamcr.2014. 03.007

Iwai M, Tateishi $\mathrm{Y}$, Hattori M, Mizutani A, Nakamura T, Futatsugi A, Inoue T, Furuichi T, Michikawa T, Mikoshiba K. 2005. Molecular cloning of mouse type 2 and type 3 inositol 1,4,5-trisphosphate receptors and identification of a novel type 2 receptor splice variant. J Biol Chem 280: 10305-10317. doi:10.1074/jbc.M413824200

Iwai M, Michikawa T, Bosanac I, Ikura M, Mikoshiba K 2007. Molecular basis of the isoform-specific ligandbinding affinity of inositol 1,4,5-trisphosphate receptors $J$ Biol Chem 282: 12755-12764. doi:10.1074/jbc. M609833200

Joseph SK. 2010. Role of thiols in the structure and function of inositol trisphosphate receptors. Curr Top Membr 66: 299-322. doi:10.1016/S1063-5823(10)66013-9

Joseph SK, Young M, Alzayady K, Yule DI, Ali M, Booth DM, Hajnóczky G. 2018. Redox regulation of type-I inositol trisphosphate receptors in intact mammalian cells. $J$ Biol Chem 293: 17464-17476. doi:10.1074/jbc.RA118. 005624

Kaplin AI, Snyder SH, Linden DJ. 1996. Reduced nicotinamide adenine dinucleotide-selective stimulation of inositol 1,4,5-trisphosphate receptors mediates hypoxic mobilization of calcium. J Neurosci 16: 2002-2011. doi: 10.1523/jneurosci.16-06-02002.1996

Kar P, Nelson C, Parekh AB. 2012. CRAC channels drive digital activation and provide analog control and synergy to $\mathrm{Ca}^{2+}$-dependent gene regulation. Curr Biol 22: 242247. doi:10.1016/j.cub.2011.12.025

Keebler MV, Taylor CW. 2017. Endogenous signalling pathways and caged-IP ${ }_{3}$ evoke $\mathrm{Ca}^{2+}$ puffs at the same abundant immobile intracellular sites. J Cell Sci 130: 3728-3739. doi:10.1242/jcs.208520

Kimlicka L, Lau K, Tung CC, Van Petegem F. 2013. Disease mutations in the ryanodine receptor $\mathrm{N}$-terminal region couple to a mobile intersubunit interface. Nat Commun 4: 1506. doi:10.1038/ncomms2501

Kuchay S, Giorgi C, Simoneschi D, Pagan J, Missiroli S, Saraf A, Florens L, Washburn MP, Collazo-Lorduy A, CastilloMartin M, et al. 2017. PTEN counteracts FBXL2 to pro- 
$\mathrm{IP}_{3}$ Receptors

mote $\mathrm{IP}_{3} \mathrm{R} 3-$ and $\mathrm{Ca}^{2+}$-mediated apoptosis limiting tumour growth. Nature 546: 554-558.

Kume S, Muto A, Inoue T, Suga K, Okano H, Mikoshiba K. 1997. Role of inositol 1,4,5-trisphosphate receptor in ventral signaling in Xenopus embryos. Science 278: 1940-1943. doi:10.1126/science.278.5345.1940

La Rovere RM, Roest G, Bultynck G, Parys JB. 2016. Intracellular $\mathrm{Ca}^{2+}$ signaling and $\mathrm{Ca}^{2+}$ microdomains in the control of cell survival, apoptosis and autophagy. Cell Calcium 60: 74-87. doi:10.1016/j.ceca.2016.04.005

Leybaert L. 2016. IP , still on the move but now in the slow lane. Sci Signal 9: fs17. doi:10.1126/scisignal.aal1929

Leybaert L, Sanderson MJ. 2012. Intercellular $\mathrm{Ca}^{2+}$ waves: mechanisms and function. Physiol Rev 92: 1359-1392. doi:10.1152/physrev.00029.2011

Li C, Chan J, Haeseleer F, Mikoshiba K, Palczewski K, Ikura M, Ames JB. 2009. Structural insights into $\mathrm{Ca}^{2+}$-dependent regulation of inositol 1,4,5-trisphosphate receptors by CaBP1. J Biol Chem 284: 2472-2481. doi:10.1074/jbc. M806513200

Li C, Enomoto M, Rossi AM, Seo MD, Rahman T, Stathopulos PB, Taylor CW, Ikura M, Ames JB. 2013. CaBP1, a neuronal $\mathrm{Ca}^{2+}$ sensor protein, inhibits inositol trisphosphate receptors by clamping inter-subunit interactions. Proc Natl Acad Sci 110: 8507-8512. doi:10.1073/pnas. 1220847110

Lin CC, Baek K, Lu Z. 2011. Apo and InsP $\mathrm{P}_{3}$-bound crystal structures of the ligand-binding domain of an $\mathrm{InsP}_{3}$ receptor. Nat Struct Mol Biol 18: 1172-1174. doi:10.1038/ nsmb.2112

Liu J, Tang TS, Tu H, Nelson O, Herndon E, Huynh DP, Pulst SM, Bezprozvanny I. 2009. Deranged calcium signaling and neurodegeneration in spinocerebellar ataxia type 2. J Neurosci 29: 9148-9162. doi:10.1523/jneurosci. 0660-09.2009

Liu Y, Sun B, Xiao Z, Wang R, Guo W, Zhang JZ, Mi T, Wang Y, Jones PP, Van Petegem F, et al. 2015. Roles of the $\mathrm{NH}_{2-}$ terminal domains of cardiac ryanodine receptor in $\mathrm{Ca}^{2+}$ release activation and termination. J Biol Chem 290: 7736-7746. doi:10.1074/jbc.M114.618827

Lock JT, Smith IF, Parker I. 2017. Comparison of $\mathrm{Ca}^{2+}$ puffs evoked by extracellular agonists and photoreleased $\mathrm{IP}_{3}$. Cell Calcium 63: 43-47. doi:10.1016/j.ceca.2016.11.006

Lopez Sanjurjo CI, Tovey SC, Prole DL, Taylor CW. 2013. Lysosomes shape Ins $(1,4,5) P_{3}$-evoked $\mathrm{Ca}^{2+}$ signals by selectively sequestering $\mathrm{Ca}^{2+}$ released from the endoplasmic reticulum. J Cell Sci 126: 289-300. doi:10.1242/jcs.116103

Luik RM, Wang B, Prakriya M, Wu MM, Lewis RS. 2008. Oligomerization of STIM1 couples ER calcium depletion to CRAC channel activation. Nature 454: 538-542. doi: 10.1038/nature07065

Magnusson A, Haug LS, Walaas I, Ostvold AC. 1993. Calcium-induced degradation of the inositol $(1,4,5)$-trisphosphate receptor/Ca ${ }^{2+}$ channel. FEBS Lett 323: 229-232. doi:10.1016/0014-5793(93)81345-Z

Mak DOD, McBride S, Foskett JK. 1998. Inositol 1,4,5-trisphosphate activation of inositol tris-phosphate receptor $\mathrm{Ca}^{2+}$ channel by ligand tuning of $\mathrm{Ca}^{2+}$ inhibition. Proc Natl Acad Sci 95: 15821-15825. doi:10.1073/pnas.95.26. 15821
Marchant JS, Taylor CW. 1997. Cooperative activation of $\mathrm{IP}_{3}$ receptors by sequential binding of $\mathrm{IP}_{3}$ and $\mathrm{Ca}^{2+}$ safeguards against spontaneous activity. Curr Biol 7: 510518. doi:10.1016/S0960-9822(06)00222-3

Marchant J, Callamaras N, Parker I. 1999. Initiation of $\mathrm{IP}_{3-}$ mediated $\mathrm{Ca}^{2+}$ waves in Xenopus oocytes. EMBO J 18: 5285-5299. doi:10.1093/emboj/18.19.5285

Marshall ICB, Taylor CW. 1994. Two calcium-binding sites mediate the interconversion of liver inositol 1,4,5-trisphosphate receptors between three conformational states. Biochem J 301: 591-598. doi:10.1042/bj3010591

Mataragka S, Taylor CW. 2018. All three $\mathrm{IP}_{3}$ receptor subtypes generate $\mathrm{Ca}^{2+}$ puffs, the universal building blocks of $\mathrm{IP}_{3}$-evoked $\mathrm{Ca}^{2+}$ signals. J Cell Sci 131: jcs220848. doi: $10.1242 /$ jcs. 220848

Miyakawa T, Maeda A, Yamazawa T, Hirose K, Kurosaki T, Iino M. 1999. Encoding of $\mathrm{Ca}^{2+}$ signals by differential expression of $\mathrm{IP}_{3}$ receptor subtypes. EMBO J 18: 13031308. doi:10.1093/emboj/18.5.1303

Miyakawa T, Mizushima A, Hirose K, Yamazawa T, Bezprozvanny I, Kurosaki T, Iino M. 2001. $\mathrm{Ca}^{2+}$-sensor region of $\mathrm{IP}_{3}$ receptor controls intracellular $\mathrm{Ca}^{2+}$ signaling. EMBO J 20: 1674-1680. doi:10.1093/emboj/20.7.1674

Nadif Kasri N, Holmes AM, Bultynck G, Parys JB, Bootman MD, Rietdorf K, Missiaen L, McDonald F, De Smedt H, Conway SJ, et al. 2004. Regulation of $\mathrm{InsP}_{3}$ receptor activity by neuronal $\mathrm{Ca}^{2+}$-binding proteins. EMBO J 23: 312-321. doi:10.1038/sj.emboj.7600037

Nunn DL, Taylor CW. 1992. Luminal $\mathrm{Ca}^{2+}$ increases the sensitivity of $\mathrm{Ca}^{2+}$ stores to inositol 1,4,5-trisphosphate. Mol Pharmacol 41: 115-119.

Paknejad N, Hite RK. 2018. Structural basis for the regulation of inositol trisphosphate receptors by $\mathrm{Ca}^{2+}$ and $\mathrm{IP}_{3}$. Nat Struct Mol Biol 25: 660-668. doi:10.1038/s41594018-0089-6

Pan L, Zhang X, Song K, Wu X, Xu J. 2008. Exogenous nitric oxide-induced release of calcium from intracellular $\mathrm{IP}_{3}$ receptor-sensitive stores via $S$-nitrosylation in respiratory burst-dependent neutrophils. Biochem Biophys Res Commun 377: 1320-1325. doi:10.1016/j.bbrc.2008.11.001

Pantazaka E, Taylor CW. 2011. Differential distribution, clustering, and lateral diffusion of subtypes of the inositol 1,4,5-trisphosphate receptor. J Biol Chem 286: 2337823387. doi:10.1074/jbc.M111.236372

Parker I, Smith IF. 2010. Recording single-channel activity of inositol trisphosphate receptors in intact cells with a microscope, not a patch clamp. J Gen Physiol 136: 119-127. doi:10.1085/jgp.200910390

Peng W, Shen H, Wu J, Guo W, Pan X, Wang R, Chen SR, Yan N. 2016. Structural basis for the gating mechanism of the type 2 ryanodine receptor RyR2. Science 354: aah5324. doi:10.1126/science.aah5324

Pizzo P, Lissandron V, Capitanio P, Pozzan T. 2011. $\mathrm{Ca}^{2+}$ signalling in the Golgi apparatus. Cell Calcium 50: 184 192. doi:10.1016/j.ceca.2011.01.006

Prakriya M, Lewis RS. 2015. Store-operated calcium channels. Physiol Rev 95: 1383-1436. doi:10.1152/physrev. 00020.2014

Prole DL, Taylor CW. 2011. Identification of intracellular and plasma membrane calcium channel homologues in 
D.L. Prole and C.W. Taylor

pathogenic parasites. PLoS ONE 6: e26218. doi:10.1371/ journal.pone.0026218

Prole DL, Taylor CW. 2016. Inositol 1,4,5-trisphosphate receptors and their protein partners as signalling hubs. $J$ Physiol 594: 2849-2866. doi:10.1113/JP271139

Rahman T, Taylor CW. 2009. Dynamic regulation of $\mathrm{IP}_{3}$ receptor clustering and activity by $\mathrm{IP}_{3}$. Channels 3: 226232. doi:10.4161/chan.3.4.9247

Rodriguez-Prados M, Rojo-Ruiz J, Aulestia FJ, GarciaSancho J, Alonso MT. 2015. A new low- $\mathrm{Ca}^{2+}$ affinity GAP indicator to monitor high $\mathrm{Ca}^{2+}$ in organelles by luminescence. Cell Calcium 58: 558-564. doi:10.1016/ j.ceca.2015. 09.002

Rooney TA, Sass EJ, Thomas AP. 1990. Agonist-induced cytosolic calcium oscillations originate from a specific locus in single hepatocytes. J Biol Chem 265: 1079210796.

Rossi AM, Taylor CW. 2019. $\mathrm{IP}_{3}$ receptors: Lessons from analyses ex cellula. J Cell Sci 132. doi:10.1242/jcs.222463

Rossi AM, Riley AM, Potter BVL, Taylor CW. 2010. Adenophostins: High-affinity agonists of $\mathrm{IP}_{3}$ receptors. Curr Top Membr 66: 209-233. doi:10.1016/S1063-5823(10) 66010-3

Saleem H, Tovey SC, Molinski TF, Taylor CW. 2014. Interactions of antagonists with subtypes of inositol 1,4,5trisphosphate $\left(\mathrm{IP}_{3}\right)$ receptor. Br J Pharmacol 171: 32983312. doi:10.1111/bph.12685

Samanta K, Parekh AB. 2017. Spatial $\mathrm{Ca}^{2+}$ profiling: Decrypting the universal cytosolic $\mathrm{Ca}^{2+}$ oscillation. J Physiol 595: 3053-3062. doi:10.1113/JP272860

Schulman JJ, Wright FA, Kaufmann T, Wojcikiewicz RJ. 2013. The BCL-2 family member bok binds to the coupling domain of inositol 1,4,5-trisphosphate receptors and protects them from proteolytic cleavage. J Biol Chem 288: 25340-25349. doi:10.1074/jbc.M113.496570

Schwaller B. 2012. Cytosolic $\mathrm{Ca}^{2+}$ buffers. Cold Spring Harb Perspect Biol 2: a004051. doi:10.1101/cshperspect.a004051

Seo MD, Velamakanni S, Ishiyama N, Stathopulos PB, Rossi AM, Khan SA, Dale P, Li C, Ames JB, Ikura M, et al. 2012. Structural and functional conservation of key domains in $\mathrm{InsP}_{3}$ and ryanodine receptors. Nature 483: 108-112. doi:10.1038/nature10751

Smith IF, Parker I. 2009. Imaging the quantal substructure of single $\mathrm{IP}_{3} \mathrm{R}$ channel activity during $\mathrm{Ca}^{2+}$ puffs in intact mammalian cells. Proc Natl Acad Sci 106: 6404-6409. doi:10.1073/pnas.0810799106

Smith IF, Wiltgen SM, Parker I. 2009a. Localization of puff sites adjacent to the plasma membrane: Functional and spatial characterization of $\mathrm{Ca}^{2+}$ signaling in SH-SY5Y cells utilizing membrane-permeant caged $\mathrm{IP}_{3}$. Cell Calcium 45: 65-76. doi:10.1016/j.ceca.2008.06.001

Smith IF, Wiltgen SM, Shuai J, Parker I. 2009b. $\mathrm{Ca}^{2+}$ puffs originate from preestablished stable clusters of inositol trisphosphate receptors. Sci Signal 2: ra77. doi:10.1126/ scisignal.2000466

Smith IF, Swaminathan D, Dickinson GD, Parker I. 2014. Single-molecule tracking of inositol trisphosphate receptors reveals different motilities and distributions. Biophys J 107: 834-845. doi:10.1016/j.bpj.2014.05.051

Sureshan KM, Riley AM, Rossi AM, Tovey SC, Dedos SG, Taylor CW, Potter BVL. 2009. Activation of $\mathrm{IP}_{3}$ receptors by synthetic bisphosphate ligands. Chem Commun 12041206. doi:10.1039/b819328b

Szabadkai G, Bianchi K, Varnai P, De Stefani D, Wieckowski MR, Cavagna D, Nagy AI, Balla T, Rizzuto R. 2006. Chaperone-mediated coupling of endoplasmic reticulum and mitochondrial $\mathrm{Ca}^{2+}$ channels. J Cell Biol 175: 901-911. doi:10.1083/jcb.200608073

Takei K, Shin RM, Inoue T, Kato K, Mikoshiba K. 1998. Regulation of nerve growth mediated by inositol 1,4,5trisphosphate receptors in growth cones. Science 282: 1705-1708. doi:10.1126/science.282.5394.1705

Tateishi Y, Hattori M, Nakayama T, Iwai M, Bannai H, Nakamura T, Michikawa T, Inoue T, Mikoshiba K. 2005. Cluster formation of inositol 1,4,5-trisphosphate receptor requires its transition to open state. J Biol Chem 280: 6816-6822. doi:10.1074/jbc.M405469200

Taylor CW. 2017. Regulation of $\mathrm{IP}_{3}$ receptors by cyclic AMP. Cell Calcium 63: 48-52. doi:10.1016/j.ceca.2016.10.005

Taylor CW, Konieczny V. 2016. $\mathrm{IP}_{3}$ receptors: Take four $\mathrm{IP}_{3}$ to open. Sci Signal 9: pe1. doi:10.1126/scisignal.aaf6029

Taylor CW, Machaca K. 2019. $\mathrm{IP}_{3}$ receptors and storeoperated $\mathrm{Ca}^{2+}$ entry: A license to fill. Curr Opin Cell Biol 57: 1-7. doi:10.1016/j.ceb.2018.10.001

Taylor CW, Tovey SC. 2012. $\mathrm{IP}_{3}$ receptors: Toward understanding their activation. Cold Spring Harb Perspect Biol 2: a004010. doi:10.1101/cshperspect.a004010

Taylor CW, Genazzani AA, Morris SA. 1999. Expression of inositol trisphosphate receptors. Cell Calcium 26: 237 251. doi:10.1054/ceca.1999.0090

Terry LE, Alzayady KJ, Furati E, Yule DI. 2018. Inositol 1,4,5trisphosphate receptor mutations associated with human disease. Messenger 6: 29-44.

Thillaiappan NB, Chavda AP, Tovey SC, Prole DL, Taylor CW. 2017. $\mathrm{Ca}^{2+}$ signals initiate at immobile $\mathrm{IP}_{3}$ receptors adjacent to ER-plasma membrane junctions. Nat Commun 8: 1505. doi:10.1038/s41467-017-01644-8

Thillaiappan NB, Chakraborty P, Hasan G, Taylor CW. 2019. $\mathrm{IP}_{3}$ receptors and $\mathrm{Ca}^{2+}$ entry. Biochim Biophys Acta doi:10.1016/j.bbamcr.2018.11.007

Thomas D, Lipp P, Berridge MJ, Bootman MD. 1998. Hormone-evoked elementary $\mathrm{Ca}^{2+}$ signals are not stereotypic but reflect activation of different size channel clusters and variable recruitment of channels within a cluster. J Biol Chem 273: 27130-27136. doi:10.1074/jbc.273.42.27130

Thurley K, Tovey SC, Moenke G, Prince VL, Meena A, Thomas AP, Skupin A, Taylor CW, Falcke M. 2014. Reliable encoding of stimulus intensities within random sequences of intracellular $\mathrm{Ca}^{2+}$ spikes. Sci Signal 7: ra59. doi:10.1126/scisignal.2005237

Tojyo Y, Morita T, Nezu A, Tanimura A. 2008. The clustering of inositol 1,4,5-trisphosphate $\left(\mathrm{IP}_{3}\right)$ receptors is triggered by $\mathrm{IP}_{3}$ binding and facilitated by depletion of the $\mathrm{Ca}^{2+}$ store. J Pharm Sci 107: 138-150. doi:10.1254/jphs. 08021FP

Tovey SC, Dedos SG, Taylor EJA, Church JE, Taylor CW. 2008. Selective coupling of type 6 adenylyl cyclase with type $2 \mathrm{IP}_{3}$ receptors mediates direct sensitization of $\mathrm{IP}_{3}$ receptors by cAMP. J Cell Biol 183: 297-311. doi:10.1083/ jcb.200803172

Tu JC, Xiao B, Yuan JP, Lanahan AA, Leoffert K, Li M, Linden DJ, Worley PF. 1998. Homer binds a novel pro- 
line-rich motif and links group 1 metabotropic glutamate receptors with $\mathrm{IP}_{3}$ receptors. Neuron 21: 717-726. doi: 10.1016/S0896-6273(00)80589-9

Tung CC, Lobo PA, Kimlicka L, Van Petegem F. 2010. The amino-terminal disease hotspot of ryanodine receptors forms a cytoplasmic vestibule. Nature 468: 585-588. doi:10.1038/nature09471

Uchida K, Aramaki M, Nakazawa M, Yamagishi C, Makino S, Fukuda K, Nakamura T, Takahashi T, Mikoshiba K, Yamagishi H. 2010. Gene knock-outs of inositol 1,4,5trisphosphate receptors types 1 and 2 result in perturbation of cardiogenesis. PLoS ONE 5: e12500. doi:10.1371/ journal.pone. 0012500

Vais H, Foskett JK, Mak DD. 2010. Unitary $\mathrm{Ca}^{2+}$ current through recombinant type $3 \mathrm{Ins}_{3}$ receptor channels under physiological ionic conditions. J Gen Physiol 136: 687-700. doi:10.1085/jgp.201010513

Vais H, Foskett JK, Ullah G, Pearson JE, Mak DOD. 2012 Permeant calcium ion feed-through regulation of single inositol 1,4,5-trisphosphate receptor channel gating. $J$ Gen Physiol 140: 697-716. doi:10.1085/jgp.201210804

Vervloessem T, Yule DI, Bultynck G, Parys JB. 2015. The type 2 inositol 1,4,5-trisphosphate receptor, emerging functions for an intriguing $\mathrm{Ca}^{2+}$-release channel. Biochim Biophys Acta 1853: 1992-2005. doi:10.1016/j.bbamcr. 2014.12.006

Vervloessem T, Kerkhofs M, La Rovere RM, Sneyers F, Parys JB, Bultynck G. 2018. Bcl-2 inhibitors as anti-cancer therapeutics: The impact of and on calcium signaling. Cell Calcium 70: 102-116. doi:10.1016/j.ceca.2017.05.014

Wagner LE II, Yule DI. 2012. Differential regulation of the Ins $\mathrm{P}_{3}$ receptor type- 1 and -2 single channel properties by InsP $\mathrm{I}_{3}, \mathrm{Ca}^{2+}$ and ATP. J Physiol 590: 3245-3259. doi:10.1113/jphysiol.2012.228320

Wang L, Yule DI. 2018. Differential regulation of ion channels function by proteolysis. Biochim Biophys Acta Mo Cell Res 1865: 1698-1706. doi:10.1016/j.bbamcr.2018. 07.004

Wang Y, Li G, Goode J, Paz JC, Ouyang K, Screaton R, Fischer WH, Chen J, Tabas I, Montminy M. 2012. Inositol-1,4,5-trisphosphate receptor regulates hepatic gluconeogenesis in fasting and diabetes. Nature 485: 128-132. doi:10.1038/nature10988

Wang L, Wagner LE II, Alzayady KJ, Yule DI. 2017. Regionspecific proteolysis differentially regulates type 1 inositol 1,4,5-trisphosphate receptor activity. J Biol Chem 292: 11714-11726. doi:10.1074/jbc.M117.789917

Wei C, Wang X, Chen M, Ouyang K, Song LS, Cheng H. 2009. Calcium flickers steer cell migration. Nature 457: 901-905. doi:10.1038/nature07577

White C, Yang J, Monteiro MJ, Foskett JK. 2006. CIB1, a ubiquitously expressed $\mathrm{Ca}^{2+}$-binding protein ligand of the
$\mathrm{InsP}_{3}$ receptor $\mathrm{Ca}^{2+}$ release channel. J Biol Chem 281: 20825-20833. doi:10.1074/jbc.M602175200

Wilson BS, Pfeiffer JR, Smith AJ, Oliver JM, Oberdorf JA, Wojcikiewicz RJH. 1998. Calcium-dependent clustering of inositol 1,4,5-trisphosphate receptors. Mol Biol Cell 9: 1465-1478. doi:10.1091/mbc.9.6.1465

Wojcikiewicz RJH. 2018. The making and breaking of inositol 1,4,5-trisphosphate receptor tetramers. Messenger 6: 45-49. doi:10.1166/msr.2018.1073

Wong AK, Capitanio P, Lissandron V, Bortolozzi M, Pozzan T, Pizzo P. 2013. Heterogeneity of $\mathrm{Ca}^{2+}$ handling among and within Golgi compartments. J Mol Cell Biol 5: 266276. doi:10.1093/jmcb/mjt024

Woods NM, Cuthbertson KSR, Cobbold PH. 1986. Repetitive transient rises in cytoplasmic free calcium in hormone-stimulated hepatocytes. Nature 319: 600-602. doi:10.1038/319600a0

Worley PF, Baraban JM, Supattapone S, Wilson VS, Snyder SH. 1987. Characterization of inositol trisphosphate receptor binding in brain. Regulation by $\mathrm{pH}$ and calcium. $J$ Biol Chem 262: 12132-12136.

Xu H, Ren D. 2015. Lysosomal physiology. Annu Rev Physiol 77: 57-80. doi:10.1146/annurev-physiol-021014-071649

Yamazaki H, Chan J, Ikura M, Michikawa T, Mikoshiba K. 2010. Tyr-167/Trp-168 in type1/3 inositol 1,4,5-trisphosphate receptor mediates functional coupling between ligand binding and channel opening. J Biol Chem 285: 36081-36091. doi:10.1074/jbc.M110.140129

Yan Z, Bai XC, Yan C, Wu J, Li Z, Xie T, Peng W, Yin CC, Li $\mathrm{X}$, Scheres SH, et al. 2015. Structure of the rabbit ryanodine receptor RyR1 at near-atomic resolution. Nature 517: 50-55. doi:10.1038/nature14063

Yang J, McBride S, Mak DOD, Vardi N, Palczewski K, Haeseleer F, Foskett JK. 2002. Identification of a family of calcium sensors as protein ligands of inositol trisphosphate receptor $\mathrm{Ca}^{2+}$ release channels. Proc Natl Acad Sci 99: 7711-7716. doi:10.1073/pnas.102006299

Yen M, Lewis RS. 2018. Physiological CRAC channel activation and pore properties require STIM1 binding to all six Orail subunits. J Gen Physiol 150: 1373-1385. doi:10.1085/jgp.201711985

Zalk R, Clarke OB, des Georges A, Grassucci RA, Reiken S, Mancia F, Hendrickson WA, Frank J, Marks AR. 2015. Structure of a mammalian ryanodine receptor. Nature 517: 44-49. doi:10.1038/nature 13950

Zeng W, Mak DD, Li Q, Shin DM, Foskett JK, Muallem S. 2003. A new mode of $\mathrm{Ca}^{2+}$ signaling by $\mathrm{G}$ protein-coupled receptors: Gating of $\mathrm{IP}_{3}$ receptor $\mathrm{Ca}^{2+}$ release channels by

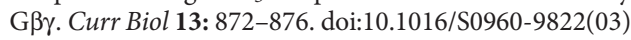
00330-0 


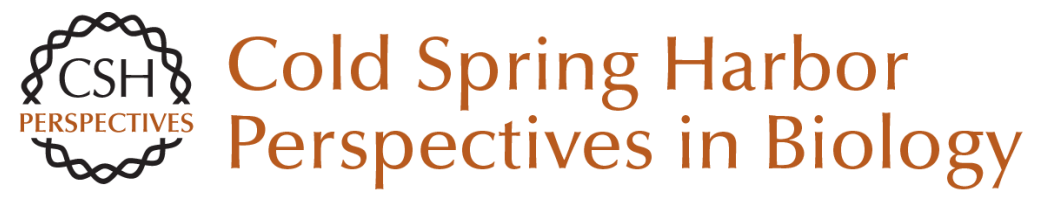

\section{Structure and Function of $\mathrm{IP}_{\mathbf{3}}$ Receptors}

David L. Prole and Colin W. Taylor

Cold Spring Harb Perspect Biol 2019; doi: 10.1101/cshperspect.a035063 originally published online February 11, 2019

\section{Subject Collection Calcium Signaling}

The Endoplasmic Reticulum-Plasma Membrane Junction: A Hub for Agonist Regulation of $\mathrm{Ca}^{2+}$ Entry

Hwei Ling Ong and Indu Suresh Ambudkar

Calcium-Handling Defects and Neurodegenerative Disease

Sean Schrank, Nikki Barrington and Grace E. Stutzmann

Lysosomal $\mathrm{Ca}^{2+}$ Homeostasis and Signaling in Health and Disease

Emyr Lloyd-Evans and Helen Waller-Evans

\section{$\mathrm{Ca}^{2+}$ Signaling in Exocrine Cells}

Malini Ahuja, Woo Young Chung, Wei-Yin Lin, et al.

Functional Consequences of Calcium-Dependent Synapse-to-Nucleus Communication: Focus on Transcription-Dependent Metabolic Plasticity Anna M. Hagenston, Hilmar Bading and Carlos Bas-Orth

Identifying New Substrates and Functions for an Old Enzyme: Calcineurin Jagoree Roy and Martha S. Cyert

Fundamentals of Cellular Calcium Signaling: A Primer

Martin D. Bootman and Geert Bultynck
Primary Active $\mathrm{Ca}^{2+}$ Transport Systems in Health and Disease Jialin Chen, Aljona Sitsel, Veronick Benoy, et al.

Signaling through $\mathrm{Ca}^{2+}$ Microdomains from Store-Operated CRAC Channels Pradeep Barak and Anant B. Parekh

Structural Insights into the Regulation of $\mathrm{Ca}^{2+}$ /Calmodulin-Dependent Protein Kinase II (CaMKII) Moitrayee Bhattacharyya, Deepti Karandur and John Kuriyan

Store-Operated Calcium Channels: From Function to Structure and Back Again Richard S. Lewis

$\mathrm{Bcl}-2-P r o t e i n$ Family as Modulators of $\mathrm{IP}_{3}$

Receptors and Other Organellar $\mathrm{Ca} 2+$ Channels Hristina Ivanova, Tim Vervliet, Giovanni Monaco, et al.

Calcium Signaling in Cardiomyocyte Function Guillaume Gilbert, Kateryna Demydenko, Eef Dries, et al.

Cytosolic $\mathrm{Ca}^{2+}$ Buffers Are Inherently $\mathrm{Ca}^{2+}$ Signal Modulators Beat Schwaller

For additional articles in this collection, see http://cshperspectives.cshlp.org/cgi/collection/

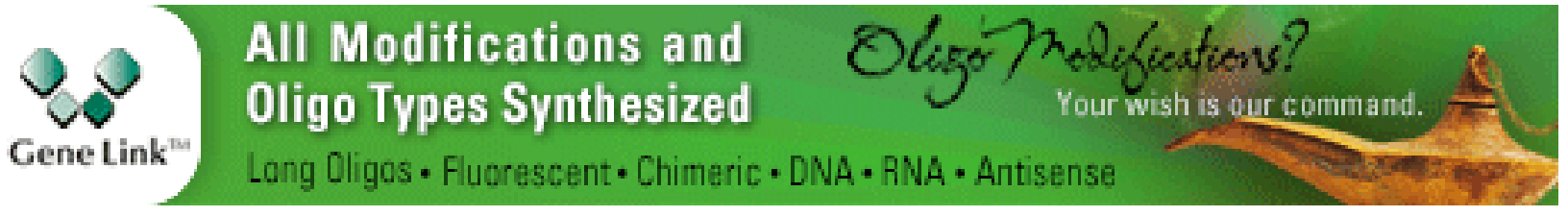


Role of Two-Pore Channels in Embryonic Development and Cellular Differentiation Sarah E. Webb, Jeffrey J. Kelu and Andrew L. Miller

\section{Organellar Calcium Handling in the Cellular \\ Reticular Network}

Wen-An Wang, Luis B. Agellon and Marek Michalak

For additional articles in this collection, see http://cshperspectives.cshlp.org/cgi/collection/

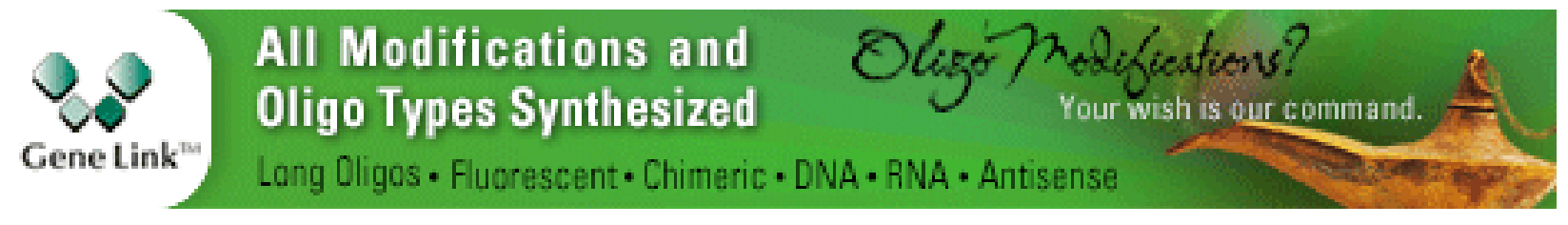

Copyright @ 2019 Cold Spring Harbor Laboratory Press; all rights reserved 